\title{
THE DISTRIBUTION OF INTERTIDAL ORGANISMS ALONG THE COASTS OF THE ENGLISH CHANNEL
}

\author{
By D. J. CRISP \\ Marine Biology Station, Menai Bridge, Anglesey \\ and A. J. SOUTHWARD \\ The Plymouth Laboratory
}

(Text-figures $\mathrm{I}-7$ )

\section{INTRODUCTION}

Our investigations on the distribution of barnacles (Crisp \& Chipperfield, 1948; Crisp, 1950; Southward, 1950, 1951 ; Norris \& Crisp, 1953; Southward \& Crisp, 1952, I954 $a$; Bishop \& Crisp, 1957, 1958) were prompted by the lack of quantitative information on the distribution of most species. During these investigations we noted that the distribution of barnacles and of other species of shore animals had certain features in common. We have therefore extended our studies to include many of the commoner intertidal organisms in the belief that we may be able to discover which are the most important of the many possible factors controlling the distribution of littoral species generally, and of barnacles in particular.

We have already described the main features of the distribution of the commoner intertidal animals along the Irish coast (Southward \& Crisp, 1954b). The present paper, the second of a series, deals with the English and French sides of the Channel. These two coasts are most conveniently treated together for several reasons. In the first place the Channel presents a simpler picture, both hydrographically and faunistically, than that afforded by the seas bounding the other coasts of the British Isles. It therefore offers a useful introduction to further contributions which we are preparing on the British Isles.

The fauna and flora of the Atlantic coast of France will be described elsewhere by one of us (D.J.C.) in collaboration with Prof. E. Fischer-Piette.

In describing distributions along the Channel coasts we have included the whole region lying between Cape Cornwall and North Foreland on the English side and the region between Calais and Le Conquet on the French side, together with Ile d'Ouessant, the Channel Islands and the Isles of Scilly. In this area we studied some of the commoner animals and plants found on predominantly rocky shores (including large boulders, piers and breakwaters). As far as possible the dominant organisms were treated quantitatively. In 
previous papers (Southward \& Crisp, 1954a, $b$, 1956) we have stressed the importance of a quantitative approach to biogeography. Some measurement of the abundance of the organisms is essential if the results are intended to be used later to check changes in distribution, and is equally important for the purpose of revealing the main controlling factors.

In two previous studies of the area, that of Moore \& Kitching (1939) on barnacles and the more general work of Fischer-Piette (1936), some quantitative information is given for certain of the species we have investigated. However, Moore \& Kitching investigated only the distribution of Chthamalus stellatus, and to a lesser extent that of B. balanoides, on the English side. Fischer-Piette, although he included species (especially of plants) that we ourselves did not investigate, omitted a detailed account of the common periwinkles and did not consider the top-shells. He concerned himself mainly with details of the distribution in the western half of the Channel, and considered particularly the effects of comparatively local factors such as tidal conditions and wave action. We have investigated the fauna throughout the Channel, and have tried to relate the patterns of distribution both to general trends in the physical environment and to such topographical details as seem to be significant.

The species investigated are listed in Table $\mathrm{I}$, together with brief references to their distribution outside the Channel and their periods of breeding. The species in brackets are those that were not investigated as fully as the other species, or those for which we had to rely upon previous observations. The terms of abundance employed in the table have exact quantitative meanings for each species, as explained in Table 2.

\section{THE PHYSICAL ENVIRONMENT}

The features of the environment most likely to influence the geographical distribution of the plants and animals of the shore can be divided into two groups. The primary factors include the temperature of the sea and the air, the salinity of the sea and its content of nutrient salts, and the currents and water movements of the sea. The variation of these factors in the Channel has been discussed by Russell (1953); they are readily defined and measured, though the information regarding them may not be complete or satisfactory as far as the intertidal zone is concerned. The other factors, including the degree of exposure to wave action and 'biological factors' attributed to water masses of different past history, are at present difficult even to define, let alone to measure.

\section{Temperature}

The monthly means of sea and air temperatures for February and August are shown in Fig. I. These months represent the overall extremes of average 
temperature for the year. At some stations slightly greater extremes of air temperature may be found in January and July.

We have already commented (Southward \& Crisp, I954 $b$ ) on the difficulty presented by the differences between the temperature of the sea and the air.

TABLE 1. THE SPECIES INVESTIGATED, THEIR GENERAL DISTRIBUTION AND MAIN BREEDING SEASONS*

\begin{tabular}{|c|c|c|c|c|c|}
\hline \multirow[b]{3}{*}{$\begin{array}{l}\text { Southern forms: } \\
\text { Anemonia sulcata (Pennant) } \\
\text { Chthamalus stellatus (Poli) } \\
\text { Balanus perforatus (Bruguière) } \\
\text { Patella depressa (Pennant) } \\
\text { P. aspera (Lamarck) }\end{array}$} & \multicolumn{2}{|c|}{ in Channel† } & \multirow{2}{*}{$\begin{array}{l}\text { North } \\
\text { European } \\
\text { limits }\end{array}$} & \multirow{2}{*}{$\begin{array}{l}\text { South } \\
\text { European } \\
\text { (or other) } \\
\text { limits }\end{array}$} & \multirow{2}{*}{$\begin{array}{l}\text { Months or season } \\
\text { of main breeding } \\
\text { period in Channel }\end{array}$} \\
\hline & $\overparen{\text { West }}$ & $\widehat{\text { East }}$ & & & \\
\hline & $\begin{array}{l}\text { A } \\
\text { A } \\
\text { A } \\
\text { A }\end{array}$ & $\begin{array}{l}R \\
N \\
N \\
N \\
N\end{array}$ & $\begin{array}{l}\text { N.W. Scotland } \\
\text { N.E. Scotland } \\
\text { S. Wales } \\
\text { N. Wales } \\
\text { Scotland, N.E. } \\
\text { England }\end{array}$ & $\begin{array}{l}\text { Med., Canaries } \\
\text { (W. Africa) } \\
\text { (W. Africa) } \\
\text { (N. Africa) } \\
\text { Spain }\end{array}$ & $\begin{array}{l}\text { May-Sept. } \\
\text { July-Sept. } \\
\text { July-Aug. } \\
\text { Sept.-Nov. }\end{array}$ \\
\hline $\begin{array}{l}\text { (Haliotis tuberculata }(\mathrm{L} .)) \\
\text { (Gibbula magus (L.)) } \\
\text { G. pennanti Philippi } \\
\text { G. umbilicalis (da Costa) } \\
\text { Monodonta lineata (da Costa) } \\
\text { Littorina neritoides (L.) }\end{array}$ & $\begin{array}{l}+ \\
\mathrm{C} \\
\mathrm{A} \\
\mathrm{A} \\
\mathrm{A} \\
\mathrm{A}\end{array}$ & $\begin{array}{l}\mathrm{N} \\
\mathrm{O}-\mathrm{R} \\
\mathrm{N} \\
\mathrm{C}-\mathrm{R} \\
\mathrm{N} \\
\mathrm{R}\end{array}$ & $\begin{array}{l}\text { N. France } \\
\text { N. Scotland } \\
\text { N. France } \\
\text { N. Scotland } \\
\text { N. W. Ireland } \\
\text { Scotland, N.E. } \\
\text { England }\end{array}$ & $\begin{array}{l}\text { Mediterranean } \\
\text { Mediterranean } \\
\text { Mediterranean } \\
\text { (Madeira) } \\
\text { (N. Africa) }\end{array}$ & $\begin{array}{l}\text { July-Sept. } \\
? ? \\
? \\
\text { Autumn } \\
\text { Autumn } \\
\text { Winter, }\end{array}$ \\
\hline (Paracentrotus lividus (Lamarck)) & + & $\mathrm{N}$ & $\begin{array}{l}\text { England } \\
\text { N.W. Ireland, }\end{array}$ & (Azores) & Probably summer \\
\hline $\begin{array}{l}\text { (Laminaria ochroleuca (la Pylaie)) } \\
\text { (Saccorhiza polysichides (Lightf.)) }\end{array}$ & + & $\stackrel{N}{N}$ & $\begin{array}{l}\text { S. England } \\
\text { W. Norway, } \\
\text { N. Scotland }\end{array}$ & $\begin{array}{l}\text { (N. Africa) } \\
\text { (N. Africa) }\end{array}$ & $\begin{array}{l}\text { Aug.-Nov. } \\
\text { Probably all year }\end{array}$ \\
\hline (Bifurcaria rotunda (Huds.)) & + & $\mathrm{N}$ & $\begin{array}{l}\text { Ireland, S. } \\
\text { England }\end{array}$ & (N. Africa) & Spring \\
\hline $\begin{array}{l}\text { Intermediate forms: } \\
\text { Actinia equina } \mathrm{L} \text {. }\end{array}$ & A & A & Murman Sea & (Africa) & $\begin{array}{l}\text { Viviparous; probably } \\
\text { all year round }\end{array}$ \\
\hline Verruca stroemia (O. F. Müller) & A & C-R & $\begin{array}{l}\text { S. Norway, } \\
\text { Iceland }\end{array}$ & Mediterranean & Nov,-May \\
\hline $\begin{array}{l}\text { Balanus improvisus Darwin } \\
\text { Elminius modestus Darwin } \\
\text { Hemioniscus balani Spence-Bate }\end{array}$ & $\begin{array}{l}\mathrm{A} \\
\mathrm{A} \\
\mathrm{A}\end{array}$ & $\begin{array}{l}\mathrm{A} \\
\mathrm{A} \\
\mathrm{R}\end{array}$ & $\begin{array}{l}\text { Baltic } \\
\text { S. W. Scotland } \\
60-62^{\circ} \mathrm{N} \text {. in } \\
\text { B. balanus }\end{array}$ & $\begin{array}{l}\text { (Tropics) } \\
\text { France ? }\end{array}$ & $\begin{array}{l}\text { May-Sept. } \\
\text { May-Oct.-Jan. } \\
\text { ? }\end{array}$ \\
\hline $\begin{array}{l}\text { Patella vulgata } \mathrm{L} . \\
\text { Gibbula cineraria }(\mathrm{L} .) \\
\text { (Calliostoma zizyphinum }(\mathrm{L} .))\end{array}$ & $\begin{array}{l}\text { A } \\
\text { A } \\
+\end{array}$ & $\begin{array}{l}\text { A } \\
\text { A } \\
+\end{array}$ & $\begin{array}{l}\text { N. Norway } \\
\text { N. Norway } \\
\text { S. Norway }\end{array}$ & $\begin{array}{l}\text { Mediterranean } \\
\text { Mediterranean } \\
\text { Mediterranean }\end{array}$ & $\begin{array}{l}\text { Oct.-Mar. } \\
\text { Probably winter } \\
\text { Probably winter and }\end{array}$ \\
\hline $\begin{array}{l}\text { Littorina obtusata (L.) } \\
\text { L. littorea (L.) } \\
\text { Fucus spiralis } \mathrm{L} \text {. }\end{array}$ & $\begin{array}{l}\text { A } \\
\text { A } \\
+\end{array}$ & $\begin{array}{l}\text { A } \\
\text { A } \\
+\end{array}$ & $\begin{array}{l}\text { Murman Sea } \\
\text { Murman Sea } \\
\text { N. Norway, } \\
\text { Iceland }\end{array}$ & $\begin{array}{l}\text { Portugal } \\
\text { Portugal } \\
\text { (N. Africa) }\end{array}$ & $\begin{array}{l}\text { Winter and spring } \\
\text { Probably all year } \\
\text { Summer }\end{array}$ \\
\hline (Himanthalia elongata $(\mathrm{L}))$. & + & $\mathrm{N}$ & $\begin{array}{l}\text { N. Norway } \\
\text { (not Iceland) }\end{array}$ & Spain & May-Oct. \\
\hline $\begin{array}{l}\text { Northern forms: } \\
\text { Balanus balanoides (L.) } \\
\text { B. balanus (L.) }\end{array}$ & $\stackrel{\mathrm{C}-\mathrm{R}}{\mathrm{N}}$ & A & $\begin{array}{l}\text { Arctic } \\
\text { Arctic }\end{array}$ & $\begin{array}{l}\text { N. Spain } \\
\text { Ireland, S. } \\
\text { Wales, S.E. } \\
\text { England }\end{array}$ & $\begin{array}{l}\text { Feb.-Apr. } \\
\text { Feb.-Apr. }\end{array}$ \\
\hline $\begin{array}{l}\text { B. crenatus Bruguière } \\
\text { Littorina saxatilis (Olivi) } \\
\text { (Laminaria digitata (Huds.)) } \\
\text { (L. hyperborea (Gunn.)) }\end{array}$ & $\begin{array}{l}\text { A } \\
\text { A } \\
+ \\
+\end{array}$ & $\begin{array}{l}\text { A } \\
\text { A } \\
+ \\
+\end{array}$ & $\begin{array}{l}\text { Arctic } \\
\text { Arctic } \\
\text { Arctic } \\
\text { N. Norway }\end{array}$ & $\begin{array}{l}\text { W. France } \\
\text { Portugal } \\
\text { N.W. Spain } \\
\text { N.W. Spain, } \\
\text { Portugal }\end{array}$ & $\begin{array}{l}\text { Feb.-May } \\
\text { All year } \\
\text { All year } \\
\text { Nov.-Apr. }\end{array}$ \\
\hline (L. saccharina (L.)) & + & + & Arctic & W. France & $\begin{array}{l}\text { Winter, but some all } \\
\text { year }\end{array}$ \\
\hline $\begin{array}{l}\text { Alaria esculenta (L.) } \\
\text { Ascophyllum nodosum (L.) } \\
\text { Fucus serratus L. }\end{array}$ & $\stackrel{+}{+}$ & $\begin{array}{l}\mathbf{N} \\
+ \\
+\end{array}$ & $\begin{array}{l}\text { Arctic } \\
\text { Arctic } \\
\text { Murman Sea, } \\
\text { White Sea }\end{array}$ & $\begin{array}{l}\text { W. France } \\
\text { Spain } \\
\text { N. Spain }\end{array}$ & $\begin{array}{l}\text { Jan.-Apr. } \\
\text { Spring } \\
\text { Autumn }\end{array}$ \\
\hline F. vesiculosus $\mathrm{L}$. & + & + & $\begin{array}{l}\text { Murman Sea, } \\
\text { White Sea }\end{array}$ & (N. Africa) & All year \\
\hline Pelvetia canaliculata (L.) & + & + & White Sea & Portugal & June-Sept. \\
\hline
\end{tabular}

* Details of distribution outside the Channel and information on breeding periods have been obtained from the following works, supplemented by personal observations where available: Forbes \& Hanley, 1853; Darwin, 1854; Sars, 1878; Woodward, 1880; Børgeson \& Jónsson, 1908; Stephenson, 1924, 1935; Mortensen, 1927; Crofts, 1929; Nobre, 1932; Hamel, 1931-39; Fischer-Piette, 1935, 1936, 1955; Fischer-Piette \& Prenant, 1956; Stephensen, 1938; Bassindale, 1941; Lami, 1941, 1943, 1954; Thorson, 1941, 1946; Station Biologique de Roscoff, 1951 $a, b$, 1954; Lilly et al. 1953; Orton et al. 1956; Marine Biological Association, 1957.

+ For meanings of symbols refer to Table 2. Parentheses round certain species indicate that our observations were incomplete. 


\section{TABLE 2. MEANINGS OF THE NOTATION USED TO DESCRIBE THE ABUNDANCE OF CERTAIN INTERTIDAL ANIMALS}

For all organisms the letters involved represent the same word: A, abundant; C, common; $\mathrm{F}$, frequent; $\mathrm{O}$, occasional; $\mathrm{R}$, rare; and $\mathrm{N}$, not found. The exact quantitative basis of these categories varies with each species, as follows:

\section{Anemones}

A Many in almost every pool and damp place

C Groups in pools and damp places

F Isolated specimens in few pools

R A small number, usually under ro, found after 30 min searching

\section{Barnacles}

For Chthamalus stellatus, Balanus balanoides and Elminius modestus, we have usually recorded numbers per square centimetre of rock. For these and other species except Balamus perforatus the categories have the following meanings:

A More than I per $\mathrm{cm}^{2}$; rocks well covered

C $\mathrm{O} \cdot \mathrm{I}$ to $\mathrm{I} \cdot \mathrm{O}$ per $\mathrm{cm}^{2}$; up to one-third of rock space covered

F d.OI to 0.1 per $\mathrm{cm}^{2}$; individuals never more than $\mathrm{IO} \mathrm{cm}$ apart

O 0.000 I to 0.01 per $\mathrm{cm}^{2}$; few within $10 \mathrm{~cm}$ of each other

$\mathrm{R}$ Less than I per $\mathrm{m}^{2}$; only a few found in 30 min searching

For $B$. perforatus, which is a much larger species, the values are:

A Over O.I per $\mathrm{cm}^{2}$; close groups on most vertical faces, often up to MTL

C 0.01 to $0 \cdot 1$ per $\mathrm{cm}^{2}$; adjacent groups, not always above LWN

F Less than o.or per $\mathrm{cm}^{2}$; adjacent in crevices

O Less than 0.01 per $\mathrm{cm}^{2}$; rarely adjacent even in crevices

$\mathrm{R}$ Only a few found in $30 \mathrm{~min}$ searching

\section{Limpets}

A Over 50 per $\mathrm{m}^{2}$ or more than $50 \%$ of limpets at certain levels

C Io to 50 per $\mathrm{m}^{2}$, Io to $50 \%$ at certain levels

F I to Io per $\mathrm{m}^{2}$, I to $10 \%$ at certain levels

O Less than I per $\mathrm{m}^{2}$ on average, less than $\mathrm{I} \%$ of population

$\mathrm{R}$ Only a few found in $30 \mathrm{~min}$ searching

$$
\text { Top-shells }
$$

A Exceeding ro per $\mathrm{m}^{2}$ generally

C I-IO per $\mathrm{m}^{2}$, sometimes very locally over Io per $\mathrm{m}^{2}$

$\mathrm{F}$ Less than $\mathrm{I}$ per $\mathrm{m}^{2}$, locally sometimes more

O Always less than I per $\mathrm{m}^{2}$

$\mathrm{R}$ Only one or two found in $30 \mathrm{~min}$ searching

\section{Periwinkles}

For the smaller species Littorina neritoides, and the small L. saxatilis found among barnacles, the ratings are:

A Over $\mathrm{I} \cdot \mathrm{O}$ per $\mathrm{cm}^{2}$ at $\mathrm{HW}$, extending down the midlittoral zone

C $O \cdot I$ to $I \cdot O$ per $\mathrm{cm}^{2}$, mainly in the supralittoral fringe

F Less than O.I per $\mathrm{cm}^{2}$, in crevices

$\mathrm{R}$ Only a few found in $30 \mathrm{~min}$ searching

For the larger littorinids the ratings are:
A More than 50 per $\mathrm{m}^{2}$
C 10 to 50 per $\mathrm{m}^{2}$
F I to ro per $\mathrm{m}^{2}$
$\mathrm{R}$ Only a few found in $30 \mathrm{~min}$ searching

The other animals, and the plants, are recorded only as present $(+)$ or absent $(\mathrm{N})$, though there may be a differentiation between forms in different habitats. 

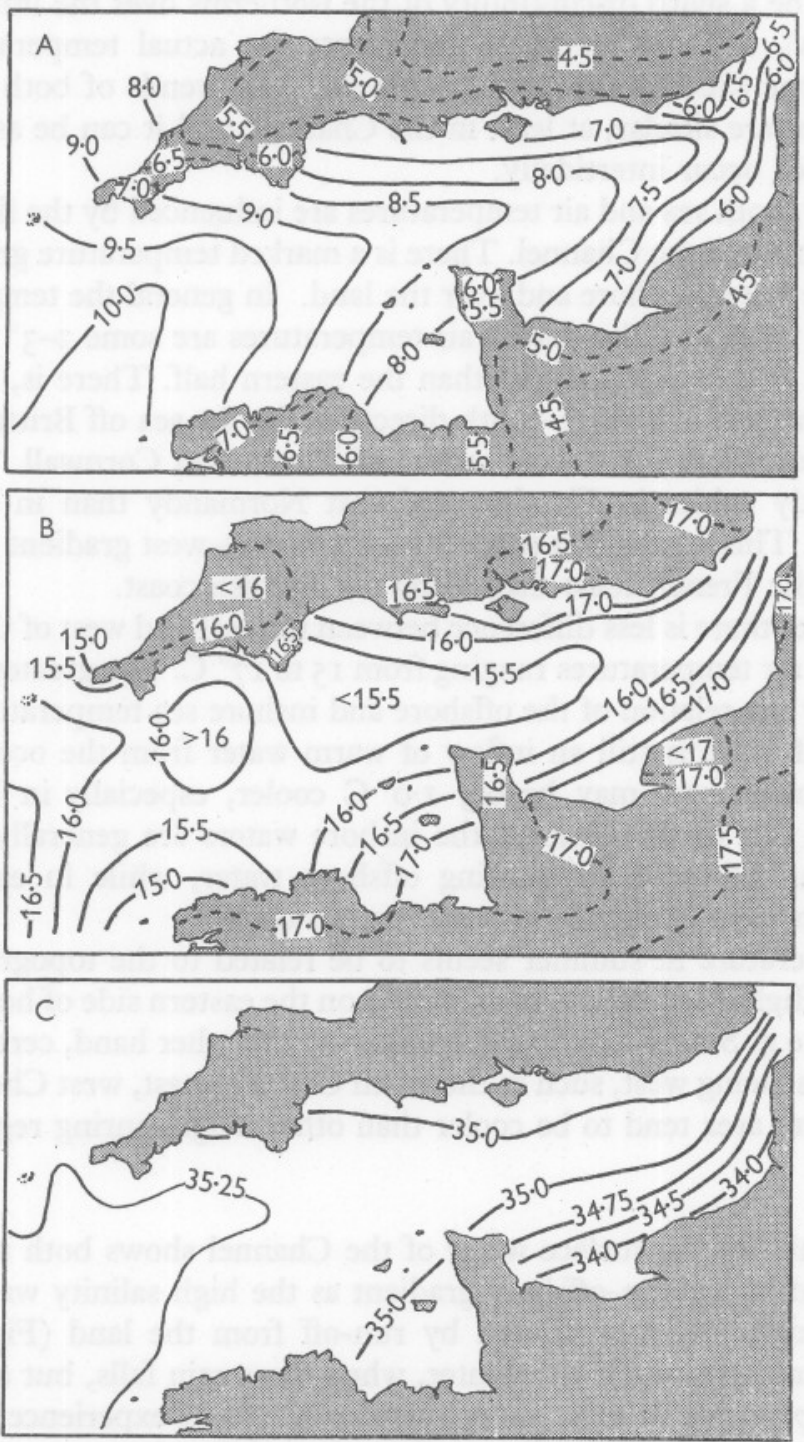

Fig. I. Some environmental factors in the Channel. A, mean sea and air temperatures for February; B, mean sea and air temperatures for August; c, mean salinity, year. Sea temperatures and salinities are taken from Lumby (1935) and represent conditions pertaining over 30 years ago. Air temperatures have been abstracted from Air Ministry (1936) and Office Nationale Météorologique (I940, I942 $a, b$ ) and isotherms drawn to show actual temperatures not corrected to sea-level; again conditions pertaining some time ago (at least 20 years) are shown. 
There may be a sharp discontinuity of the isotherms over the intertidal zone (cf. Fig. IA), and neither figure represents the actual temperature of the intertidal zone (Southward, I958). However, the trends of both sea and air temperatures are similar, at least in the Channel, and it can be assumed that similar trends occur intertidally.

In winter, both sea and air temperatures are influenced by the flow of water eastwards through the Channel. There is a marked temperature gradient from the offshore water, inshore and over the land. In general the temperatures of the inshore water and the coastal air temperatures are some $2-3^{\circ} \mathrm{C}$ higher in the western half of the Channel than the eastern half. There is, in addition, a further gradient in a north-south direction, for the sea off Brittany is about $0.5^{\circ} \mathrm{C}$ warmer than the coastal waters of Devon and Cornwall. The coastal air is slightly colder in Flanders and east Normandy than in Sussex and south Kent. This means that there is a steeper east-west gradient of temperature along the French coast than along the English coast.

In summer there is less difference between the east and west of the Channel, the sea and air temperatures ranging from 15 to $17^{\circ} \mathrm{C}$. The greatest difference is shown by the relation of the offshore and inshore sea temperatures. In the western half there is still an inflow of warm water from the ocean, and the inshore temperatures may be $0.5-\mathrm{I} \cdot 0^{\circ} \mathrm{C}$ cooler, especially in Brittany: in the eastern part of the Channel the inshore waters are generally $\mathrm{I} \cdot \mathrm{O}-\mathrm{I} \cdot 5^{\circ} \mathrm{C}$ warmer than the eastward flowing offshore water, while in estuaries and shallow bays even greater local warming can occur.

Air temperature in summer seems to be related to the topography of the coastline. Higher temperatures are found on the eastern side of headlands and peninsulas, e.g. Start Pt. and Cherbourg. On the other hand, certain exposed coastal areas facing west, such as the north Cornish coast, west Cherbourg and the Le Havre area tend to be cooler than other neighbouring regions.

\section{Salinity}

The salinity of the surface water of the Channel shows both an east-west gradient and an inshore-offshore gradient as the high salinity water entering from the ocean becomes diluted by run-off from the land (Fig. IC). The differences are greatest in the winter, when more rain falls, but are probably of little importance to most shore organisms, which experience larger local changes in salinity from the direct effect of rainfall and streams on the shore.

\section{Nutrient salts}

As far as can be ascertained there are no great differences in the phosphate and nitrate resources of the main body of water in different parts of the Channel proper. Locally rich patches of lower salinity and high silicate content, however, occur in the vicinity of estuaries, while richer high salinity water may be found off the Channel mouth (Harvey, I930; Kalle, I937). 


\section{Tides, currents and water movements}

If we divide the Channel by a line running from Swanage to Cherbourg we find that in the two basins thus formed the tides are out of phase. In the western basin the maximum spring tides occur at midday and midnight, while in the eastern basin they occur in the early morning and evening. Fast tidal currents are found where the two basins join, especially off headlands such as St Catherine's Pt., The Needles, St Alban's Head, Portland Bill, Cap de la Hague and Alderney. The greatest and smallest tides of the Channel are found in this middle section also. The least tides occur on the English side, where the shallow water effects are large and produce the 'double' or 'abnormal' tides of Portland, Swanage and the Isle of Wight. On the French side very big tides occur in the Gulf of St Malo.

The main residual current is up-Channel, the direction of the prevailing winds. Water enters at the western end and passes eastwards through the Straits of Dover. Carruthers (1930) has described the routes taken by drift bottles liberated in the western Channel, while more recently measurements of the total flow through the Straits of Dover have been made by Bowden (1956). It need scarcely be pointed out that the rate of exchange of water with the Atlantic is much greater in the western section of the Channel than it is in the eastern part. Little is known of the minor eddies and counter currents which may exist near the coast and which may be of greater importance in dissemination of larval stages of many intertidal species. A counter eddy has been established in Pevensey Bay from current measurements made at the Varne lightship (Carruthers, 1935; Carruthers, Lawford \& Veley, 1950). Counter currents are also indicated on either side of the main drift through the Straits of Dover by Van Veen (1936). It is possible that a counter current sometimes flows eastwards along the south coast of Cornwall and flows clockwise round the south-west peninsula towards the Bristol Channel, but current measurements at the Seven Stones Light Vessel, between Scilly and Land's End, show a residual drift in the direction E.S.E. (Carruthers, Lawford, Veley \& Gruning, 195I).

On theoretical grounds the water movements up-Channel would be expected to be deflected southwards very slightly by Corioli's force, while those downChannel would be deflected northwards. Thus the main residual flow from west to east would have a tendency to hug the French coast, while counter currents might be expected to develop more readily on the English side. However, Corioli's force influences mainly the movement of large water masses which are moving freely with their own inertia. The surface layers of water, and especially those close to the shore where friction with the sea bed is important, however, should tend to follow the direction most closely approximating to that of the wind consistent with the lie of the shoreline. 


\section{Wave-action and substratum}

The effects of wave-action on the plants and animals of the shore are modified by the type and configuration of the shoreline and the depth of water offshore, and these factors are interrelated. This fact does not seem to have been realized by previous workers, who assessed wave-action on the basis of topography or orientation to prevailing winds (Moore, I935; Lysaght, I94I). Over small areas of coastline it is sometimes possible to assess waveaction by relating a series of measurements of wave wash above normal tidal height with winds of a certain direction and strength (Southward, r953), but this method fails on coasts open to ocean swell (Southward \& Orton, 1954).

On gently shelving rocky ledges wave wash may surge great distances up the shore, while on very broken rocky reefs splash may be the main effect. The mechanical action of waves also depends upon the nature of the shore; on steep slopes there will be great dynamic shock, while on shelving shore there will be mainly a tearing or shearing effect. Moreover, the presence of submerged reefs or bars offshore may reduce wave-action on the shore or may modify the type of wave reaching the shore (Bigelow \& Edmonson, r947).

We are thus as far as ever from the attainment of some measure of waveaction, since so much depends on local factors. Local factors are even more important on depositing shores, or where large amounts of mud, sand or gravel are found offshore. These particles are moved or brought into suspension, according to their size and the power of the waves, and can scour the rocky parts of the coast. In general, the greater the wave-action at a place, the larger the particles remaining to be moved or affected by wave-action, for the smaller particles have been removed (cf. de Martonne, I935). Thus headlands jutting out into deep water, though they receive greater pounding by waves, generally show little scour, while bays with accumulations of sand or gravel, though often receiving less wave-action, may be exposed to greater damage by scour. The scouring action of gravel seems to be especially severe, and predominantly gravel shores are virtually intertidal deserts.

The western half of the Channel is bounded by a steep rocky shoreline indented at intervals by drowned valleys and sandy bayhead beaches, and deep water is never far offshore. Largely because its shores consist of softer material the eastern half of the Channel has a more even coastline, and the great accumulations of sand and shingle form gently shelving beaches. The eastern basin is shallow and wave-induced movements must often disturb the sea bed. Thus in the eastern Channel the water carries much suspended matter, and near the shores the waves cause continual abrasion through the sand and shingle that they churn up. This abrasion is most marked near highwater mark where the largest stones are found and where the waves break with greatest force. In the western basin, however, the water is generally clearer, and carries little particulate material; the shores are wave-beaten rather than 
scoured. This generalization is true only in so far as these shores are of harder rock; where the rock is more friable, or where much material is brought down by rivers, coastal conditions approximate to those of the eastern end of the Channel. Thus the coasts surrounding the Helford River, the Fal and Fowey, Plymouth Sound, Salcombe and the Dart are locally silty and muddy with turbid water at spring tides and after rain. Mounts Bay is extensively sandscoured, while much of Lyme Bay has accumulations of shingle, culminating in the famous Chesil Bank. The scour experienced by many of the coasts lying between the Exe and Chesil Bank must surely equal or exceed that suffered anywhere to the east of Portland. Nevertheless, the Channel water as a whole remains very clear throughout most of its length as far as the Isle of Purbeck. Only where the Channel narrows and shallows to the east of the Isle of Wight does the water near the shore become almost continuously turbid.

Similar conditions apply to the French coast. The long estuaries of Finistère and the Côtes du Nord produce locally turbid conditions, and the scour is probably greater than in corresponding drowned valleys on the English side, on account of the greater tidal range. The Gulf of St Malo, particularly towards its south-eastern corner, is in some respects analogous to West Bay. Its coasts have been eroded to produce much sand, gravel and shingle, which is prevented from being driven eastwards by the Cherbourg peninsula. Hence this loose material has accumulated both in the bay, reducing its depth, and on the westfacing shores south of Carteret where the scour appears to be severe.

Two small but important differences between the French and English coasts should be referred to here. First, at the extreme western end of the Channel the coast of north Finistère is less steep than that of south Devon and Cornwall, and is protected by numerous offshore reefs and islands. Moreover, the predominant wind at the mouth of the Channel, which is south of west, blows almost directly on to the coast of south-west England, while northern Finistère lies slightly in the lee of the Armoricaine peninsula. Hence a considerable part of the latter coast, excluding the offshore islands, is less exposed to wave-action; in general, it retains more loose material in the shape of sandy beaches and boulder spits (e.g. Sillon de Talbert) than corresponding regions of the English coast. Secondly, at the extreme eastern end of the Channel, the English side is composed entirely of soft chalks, sands and alluvium, yielding intertidally only chalk reefs and sand or shingle beaches. On the Boulonnais coast, however, exposures of oolite face the prevailing winds and give rise to more typical rocky shores below H.W.N., even though banks of shingle may form at high-water mark.

It is worth pointing out that geological factors profoundly influence the formation and character of tide pools, which are the main habitat of some animals and plants. In the eastern part of the Channel the rocks are usually too friable or too flat-bedded to allow the formation of other than shallow pools, which are often filled with sand or other deposits. 
The main differences between the two halves of the Channel are summarized in Table 3.

\begin{tabular}{|c|c|c|}
\hline Factor & West & East \\
\hline Summer temperature & Little lower & Little higher \\
\hline Winter temperature & Higher & Lower \\
\hline Average temperature & Higher & Lower \\
\hline Tendency to frosts & Slight & Considerable \\
\hline Average sea salinity & Higher & Lower \\
\hline Nutrient salts & Little difference & Little difference \\
\hline Biological factors & $\begin{array}{l}\text { Decreasing from } \\
\text { west to east? }\end{array}$ & Not known \\
\hline Tidal currents & \multicolumn{2}{|c|}{ (very great in middle) } \\
\hline Scour & Little & Much \\
\hline Silt in suspension & Little & Much \\
\hline Rocky substratum & Much & Less \\
\hline Pollution & Some & More \\
\hline Wave-action & More & $\begin{array}{l}\text { Less, but bottom } \\
\text { disturbance greater }\end{array}$ \\
\hline $\begin{array}{l}\text { Depth of water } \\
\text { Thermocline in summer }\end{array}$ & More & Less \\
\hline Thermocline in summer & Probably stable & $\begin{array}{l}\text { Probably disturbed } \\
\text { in shallower water } \\
\text { by currents }\end{array}$ \\
\hline
\end{tabular}

THE DISTRIBUTIONS

The main trends in distribution of the organisms investigated have already been summarized in Table I. The detailed distribution of the commoner animals is set out in Table 7 (appendix). We have not tabulated in detail our results for the algae, as these were not as completely investigated as the animals on the English side of the Channel. The algal distributions, and those of some of the less common animals also investigated in less detail, are commented upon below, after the commoner animals.

\section{Anemonia sulcata COMMONER ANIMALS}

The records for Anemonia sulcata in Table 7 refer mainly to positive occurrences, as the species may be found only at extreme low water and its complete absence from a locality cannot always be stated with certainty. The records refer to both ecological forms of the species, the one in pools in the upper midlittoral and the other among algae in the infralittoral fringe. Both forms are common in the western part of the Channel, but only the low-water form occurs towards the east. The species penetrates sporadically into the eastern basin, the most easterly records being at Brighton and Grandcamp.

\section{Actinia equina}

The commoner of the two species of sea-anemone investigated, Actinia equina, occurs throughout the Channel. Fischer-Piette (1936) regarded the distribution of the species as 'capricious', and his charts show areas of greater 
or lesser abundance. Our results differ: we found the species common at some localities where he did not find it, for example Tremazan and Cancale, and no general trend in distribution could be made out, save that the greater area of suitable rocky substratum at the western end of the Channel resulted in the species being found at a greater proportion of the stations than in the eastern basin.

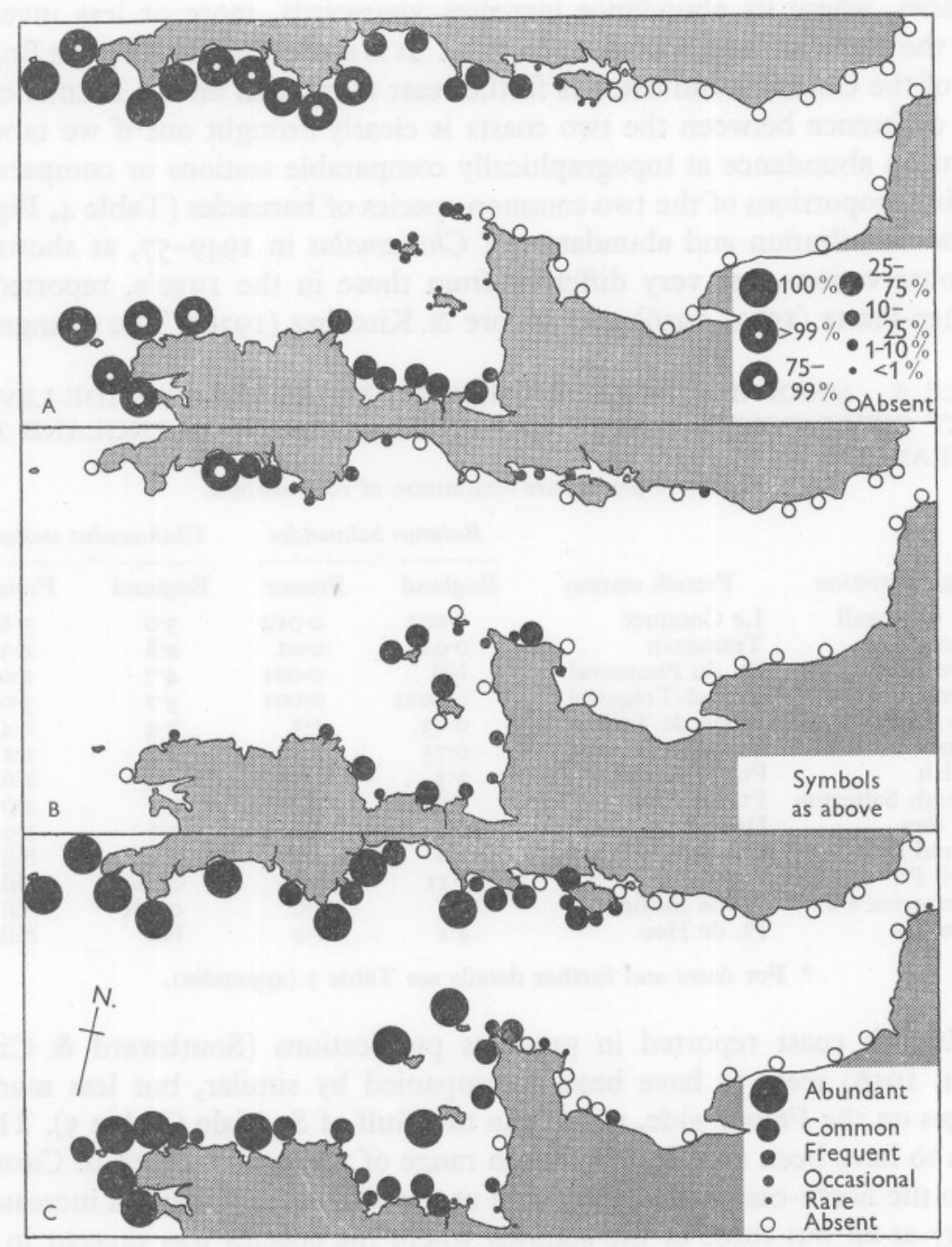

Fig. 2. Distribution of some representative species in the Channel. A, confined exclusively to the western part; Chthamalus stellatus, shown as percentage of population of Chthamalus and Balanus balanoides; $\mathrm{B}$, common in the west and rare in the east; Hemioniscus balani, shown as percentage infection of Balanus balanoides; $\mathrm{c}$, present in the eastern basin on the French side only; Littorina neritoides. 
Possibly the abundance of Actinia varies greatly from year to year, or over quite small distances on the shore. No doubt the viviparous habit of breeding would contribute to such variation.

\section{Chthamalus stellatus}

The barnacle Chthamalus stellatus is confined to the western half of the Channel, where its abundance increases westwards, more or less inversely with the abundance of Balanus balanoides. It is more abundant on the English side of the Channel, and extends farther east there than on the French coast. The difference between the two coasts is clearly brought out if we tabulate the mean abundance at topographically comparable stations or compare the relative proportions of the two common species of barnacles (Table 4, Fig. 2).

The distribution and abundance of Chthamalus in 1949-57, as shown by our observations, are very different from those in the 1930's, reported by Fischer-Piette (1932, 1936) and Moore \& Kitching (1939). The changes on

TABLE 4. MEAN BARNACLE COUNTS TAKEN AT THREE TIDE-LEVELS AT CORRESPONDING STATIONS ON THE COASTS OF ENGLAND AND FRANCE*

Numbers per square centimetre of rock surface.

\begin{tabular}{|c|c|c|c|c|c|}
\hline \multirow[b]{2}{*}{ English station } & \multirow[b]{2}{*}{ French station } & \multicolumn{2}{|c|}{ Balanus balanoides } & \multicolumn{2}{|c|}{ Chthamalus stellatus } \\
\hline & & England & France & England & France \\
\hline Cape Cornwall & Le Conquet & 0.002 & 0.012 & 3.0 & 3.8 \\
\hline Sennen Cove & Tremazan & 0.02 & 0.02 & $2 \cdot 8$ & $2 \cdot 3$ \\
\hline Lizard Head & Pt. du Pontusval & Nil & 0.001 & 4.7 & $2 \cdot 0$ \\
\hline Polkerris & Primel-Trégastel & 0.0001 & 0.001 & $3 \cdot 2$ & $3 \cdot 0$ \\
\hline Hope Cove & Sillon de Talbert & 0.03 & $I \cdot 3$ & 3.4 & I. 4 \\
\hline Brixham & St Quay-Portrieux & 0.75 & 2.5 & $2 \cdot 8$ & $2 \cdot I$ \\
\hline Dawlish & Pt. du Roselier & $2 \cdot 3$ & $I \cdot 3$ & 3.5 & $2 \cdot 6$ \\
\hline Budleigh Salterton & Pt. de Pléneuf & $3 \cdot 0$ & I. 4 & $2 \cdot 5$ & $4 \cdot 0$ \\
\hline West Bay & Dinard & 0.9 & $2 \cdot I$ & $2 \cdot 6$ & I.9 \\
\hline Portland Bill & Cap de la Hague & $I \cdot 0$ & $>\mathrm{I} \cdot \mathrm{O}$ & 2.9 & Nil \\
\hline Peveril Pt. & Cap Lévy & 0.11 & $>\mathrm{I} \cdot \mathrm{O}$ & 0.12 & Nil \\
\hline St Catherine's Pt. & Pt. de Barfleur & 0.5 & $>\mathrm{I} \cdot \mathrm{O}$ & 0.001 & Nil \\
\hline Bembridge & Pt. de $\mathrm{Hoc}$ & $4 \cdot I$ & $>\mathrm{I} \cdot \mathrm{O}$ & Nil & Nil \\
\hline
\end{tabular}

the English coast reported in previous publications (Southward \& Crisp, I954a, 1956) seem to have been accompanied by similar, but less marked changes on the French side, notably in the Gulf of St Malo (Table 5). There seems to have been a slight increase in range of the species north of Carteret and to the north-east of Alderney, and at the same time a marked increase in density at all but three of the stations where the species was present in the 1930's. The increase appears to have been most marked in the outermost Channel Islands, Alderney and Guernsey, where Chthamalus is now present in greater numbers than in Jersey, a reversal of the previous situation. 
TABLE 5. CHANGES IN THE ABUNDANCE OF CHTHAMALUS STELLATUS AT STATIONS IN THE GULF OF ST MALO

As maximum density per square centimetre, or ratio to Balanus balanoides. Brackets indicate nearby stations, to be compared with each other.

\begin{tabular}{|c|c|c|}
\hline & $\begin{array}{c}1930-32 \\
\text { (from Fischer-Piette, 1932, 1936) }\end{array}$ & $1954-6$ \\
\hline Cap de la Hague & Absent & Absent \\
\hline $\begin{array}{l}\text { Nez de Jobourg } \\
\text { Vauville }\end{array}$ & & $0.0005{ }^{\circ}$ \\
\hline Flamanville & Absent & \\
\hline Carteret & 0.01 & 0.01 \\
\hline Granville & I: 20 at H.W.N. & $3: 4$ at H.W.N. \\
\hline $\begin{array}{l}\text { Clonque } \\
\text { Chateau a l'Etocl }\end{array}$ & $\begin{array}{l}0.0005 \\
\text { Absent) }\end{array}$ & 0.5, \\
\hline Pt. Quesnard & & $0.004^{\prime}$ \\
\hline La Moye Pt. & 0.006 & 0.36 \\
\hline Fort Doyle & $\begin{array}{l}\text { O.OOOI } \\
\text { Yery rare, just above unner }\end{array}$ & 0.01 \\
\hline Montorgueil Castle & $\begin{array}{l}\text { Very rare, just above upper } \\
\text { limit } B \text {. balanoides }\end{array}$ & 0.01 \\
\hline Plemont Pt. & $\begin{array}{l}\text { Very rare, just above upper } \\
\text { limit } B \text {. balanoides }\end{array}$ & 0.04 \\
\hline La Corbière & $\begin{array}{l}\text { Very rare, just above upper } \\
\text { limit } B \text {. balanoides }\end{array}$ & 0.015 \\
\hline Cancale & I: 20 at M.T.L. & 2:I at M.T.L. \\
\hline $\begin{array}{l}\text { Dinard } \\
\text { Pt. du Decollé }\end{array}$ & $\overline{I: I}$ at M.T.L. & S.4 al M.T.L. \\
\hline Pt. de Pléneuf & I: I at M.T.L. & $2: I$ at M.T.L. \\
\hline Pt. de Pordic & 3:I at M.T.L. & $4: 5$ at M.T.L. \\
\hline Sillon de Talbert & $2: 3$ at M.T.L. & I:3 at M.T.L. \\
\hline
\end{tabular}

\section{Balanus balanoides}

The common acorn barnacle Balanus balanoides is present throughout the Channel. Our records agree generally with those of Fischer-Piette (I932, 1936; personal communications) except for south-west England where the species is less abundant than formerly. During 1949-57 B. balanoides was rare west of Plymouth and was absent from the Isles of Scilly and the extreme south-west of Cornwall (Figs. 2, 6). The species was more common on the French coast opposite, and was found without difficulty at most stations examined between Roscoff and the Rade de Brest, though frequently confined to low water and never very common. Comparison of representative stations on both sides of the Channel (Table 4) shows that the species is generally more abundant on the French side. Only at two pairs of stations is the incidence of B. balanoides less on the French side. The French stations in these cases, Pt. du Roselier and Pt. de Pléneuf, are relatively exposed headlands, while the corresponding English stations do not stand out from the coastline.

On both coasts of the western basin the abundance of $B$. balanoides increases towards the east, but not uniformly. There is a region of reduced density on the English coast, from West Bay to St Catherine's Pt., that is not paralleled by a corresponding reduction on the opposite coast. As Chthamalus stellatus is also reduced in abundance at many of the stations in the same area, the 
reduction cannot well be attributed to effects of temperature or wave-action. It seems possible that the small tidal range in the region may reduce the stocks of adults to a point where there is difficulty in producing sufficient larvae for more abundant settlement. The strong tidal currents may also be detrimental to settlement of larvae and may hinder recruitment from more distant stocks of adults.

Our observations support and extend previous conclusions as to the influence of habitat on the abundance of barnacles in the Channel (FischerPiette, 1936; Southward \& Crisp, I954a, 1956). In the western basin $B$. balanoides thrives better and grows to a larger size in the estuaries and harbours than on the open coast. In the eastern part of the Channel it is dominant on the open coast, and in sheltered bays and harbours is replaced by Eliminius modestus. On shores composed largely of chalk rocks, as for example at Lulworth Cove, Rottingdean, North Foreland, Cap Blanc Nez and Fécamp, B. balanoides, in common with other species of barnacles present, was reduced in number and occurred only sporadically or in sparsely scattered groups. Similar low barnacle counts were found on other soft rocks, such as the Wealden clays exposed at Brook and Fairlight. The relative paucity of barnacles on soft substrata has been commented on previously (Southward \& Crisp, 1954b), and has been attributed to porosity, with consequent desiccation through the basis (Moore \& Kitching, 1939) or to the enhanced erosive activities of limpets on such rocks (Hawkshaw, 1878). The poor adhesion of the base on soft rocks must be a contributory factor, together with the scouring effects of the loose flints that are almost always present on chalk shores, and all these factors probably operate together on the open coast. In sheltered waters, however, where there is little wave-action, where limpets are less abundant and where loose substrata do not move, barnacles may be found in good number on soft materials.

\section{Balanus perforatus}

Like Chthamalus, Balanus perforatus is confined to the western half of the Channel, and is not found east of the Isle of Wight or Cotentin. B. perforatus, in recent years, seems also to have undergone an increase in abundance, which may have begun in the 1930's or earlier, for Fischer-Piette (1936) remarked on an increase in the Channel Islands between 1930 and 1935. No doubt, as a southern species, $B$. perforatus might be expected to benefit from any general increase in temperature, such as occurred in the Channel in recent years (Southward \& Crisp, 1954 $a$; Cooper, 1958). It breeds and settles in a limited period of the late summer and autumn (Norris \& Crisp, 1953), and would receive most benefit from the warm autumns that have been a marked feature of the climatic amelioration. Nevertheless, the evidence for increased abundance of this species must be viewed with caution. It is a barnacle that may 
be surprisingly locally distributed, and one that is profoundly influenced by wave-action and the configuration of the shore. Observations of its abundance may be very subjective, and we ourselves have noted considerable differences in our individual assessments of its abundance at a station. For these reasons it is difficult to compare our results with those of Fischer-Piette (1936), though we have tried to do so (Table 6). In considering the earlier observations, it is hard to believe that in 1932 B. perforatus was absent from Wembury (it was recorded by Colman, 1933) or the Isles of Scilly, though the abundance may have been less than it is now. This throws some doubt on the apparent changes that have occurred at the other English stations.

TABLE 6. RELATIVE ABUNDANCE OF BALANUS PERFORATUS AT STATIONS ON THE ENGLISH COAST

$\begin{array}{lcc} & \begin{array}{c}\text { I930-2 } \\ \text { (from Fischer- } \\ \text { Piette, I936) }\end{array} & \begin{array}{l}\text { I949-57 } \\ \text { St Catherine's Pt. }\end{array} \\ \text { Portland Bill } & \text { O-R } & \text { O } \\ \text { Straight Pt. } & \text { A } & - \\ \text { Budleigh Salterton } & \text { C } & \text { A } \\ \text { Brixham } & \text { O-R } & \text { A } \\ \text { Prawle } & \text { N } & \text { A } \\ \text { Wembury ('Blackstone Pt.') } & \text { C } & \text { A } \\ \text { Rame Hd. } & \text { O-R } & \text { C } \\ \text { Lizard Hd. } & \text { C } & \text { A } \\ \text { Lamorna Cove ('Carn du Pt.') } & \text { O-R } & \text { C } \\ \text { Cape Cornwall } & \text { N } & \text { F-A }\end{array}$

These terms of abundance are explained in Table 2. We have converted Fischer-Piette's terms as follows: Grande abondance, A; Abondance moyenne, C; Faible, F; Très faible, O-R.

We can, however, be certain that Fischer-Piette's evidence that B. perforatus was commoner on the French side of the Channel no longer holds good. In fact, at the western extremity, the species is commoner on the English side. Notable changes seem to have taken place in the Channel Islands, as with Chthamalus stellatus. Thus, in Alderney and Guernsey, where Balanus perforatus was reported 'très faible' or absent in I93I, we found it to be quite common at most exposed places and extremely abundant on the outer edges of the reefs. In Jersey, on the other hand, the species appeared to be rather uncommon, and only in the north-west of the island did we find it in numbers approaching those present on the outer two islands. We did not see the species at two stations where it was reported previously to be 'faible' or 'très faible', probably because our visit did not allow each station to be worked on a very low tide.

The revised distributions of $B$. perforatus and Chthamalus in the Gulf of St Malo agree well with one another (Fig. 5, p. 184). Both are relatively common on the coasts of Ille-et-Vilaine and Côtes-du-Nord, and become scarce along the western coast of Cotentin. They are both rather uncommon in 
Jersey, and more abundant in Alderney and Guernsey, although Chthamalus is not there as abundant as on the coasts of Ille-et-Vilaine and Côtes-du-Nord. If we compare the extreme limits of Balanus perforatus in 1930-32 and 194957 , there would seem to have been an extension of range eastwards along the English coast, corresponding to the extension of Chthamalus during the same period. Fischer-Piette (I936) did not find the species east of St Alban's Head: it is now common in Poole Harbour (Norris \& Crisp, 1953), and can be found without difficulty in parts of south Hampshire and the Isle of Wight. Dr H. G. Stubbings informs us that occasionally he has found spat of Balanus perforatus on settlement panels exposed at the entrance to Chichester harbour, but so far we have been unable to find any adult specimens in Sussex.

$B$. perforatus is sometimes locally much commoner in bays and fairly saline estuaries than on the open coast as, for example, in the Halford and Fal estuaries as compared with the Lizard peninsula (Fig. 6, p. I9I). However, it can be very abundant in some exposed situations, and there is no general rule that the species is commonest in embayed situations, as might be inferred from Fischer-Piette's evidence. The species is extremely abundant on the Eddystone rocks, off Plymouth, and on the outermost blocks of the Plymouth breakwater, both isolated sites where wave-action is severe and prolonged. The species is also common on sand-scoured reefs in Mounts Bay and Whitsand Bay. The action of the waves, whether accompanied by scouring effects or not, does not therefore seem to be directly inimical to the species.

\section{Balanus crenatus}

We have not been able to investigate Balanus crenatus in sufficient detail because, on the open coast, it is often present only at extreme low-water mark. Our records, as far as they go, indicate that the species is generally distributed along the Channel, though possibly more in evidence at the eastern end. In the western half of the Channel B. crenatus resembles B. balanoides and Elminius in growing better in estuaries and harbours than on the open coast. Specimens from the Dart, Plym, Penzé and l'Aber Beniot estuaries commonly reach I 5-20 $\mathrm{mm}$ in diameter, and may occur up to M.T.L., compared with sizes of 6-9 $\mathrm{mm}$ at extreme low water on the open coast.

This species, of course, is very common in the infralittoral zone and may be very abundant on the shells of molluscs and crustaceans dredged from shallow water.

\section{Balanus improvisus}

We have included the estuarine species Balanus improvisus in our records for comparison with Elminius modestus, which is replacing it in many of its habitats. Balanus improvisus was present throughout the Channel in the estuaries, from the Helford and l'Aber Beniot in the west, to the Rother and Boulogne in the east. 


\section{Elminius modestus}

Detailed accounts of the spread of the immigrant Australasian barnacle Elminius modestus along the Channel coasts will be found elsewhere (den Hartog, 1956; Crisp, 1958; Bishop \& Crisp, 1957, 1958). During the later part of the survey the species was abundant in the eastern part of the Channel, but common only in the estuaries and harbours in the west. On both sides of the Channel there was, in 1954-56, an intermediate region in which Elminius had not established itself. On the English side it was absent from the greater part of Lyme Bay: on the French side the uncolonized area was larger, and included the whole of the Gulf of St Malo and the Channel Islands.

\section{Verruca stroemia}

We have attempted to study the distribution of the low-water species Verruca stroemia in more detail than the other species found only at the lower levels of the shore, since its general European distribution is intermediate between the distributions of the typically northern or southern species. Verruca is most commonly found in shallow water below the tide marks, but may be quite abundant in the infralittoral fringe in places. Its most favoured habitat is on the undersides of rocks and stones where there is little movement of the substrate, but where there is enough water movement to prevent the deposition of large amounts of silt. Incomplete observations on Verruca suggest that it may be restricted by its feeding habits to places with some water currents, for it does not always set up a current by rapid beating of the cirri as other barnacles do (cf. Southward, I955c).

Where conditions are satisfactory the species can be very abundant in the intertidal zone, as for example at Brixham, as noted by Fischer-Piette (1936), on the stones and boulders of the breakwater. At Plymouth it can be found in widely distinct habitats such as the outer reefs at Wembury, and the fairly silty conditions at Hen Pt. in the Tamar. Verruca is common on most shores at the western end of the Channel, but seems to become sparser eastwards. The most easterly record, where two or three specimens only were found, is Fairlight, Sussex. The relatively scanty records may perhaps be filled in by use of planktonic occurrences of the larvae, which are quite distinctive (Bassindale, 1936), but this method inevitably takes account of infralittoral populations also. It seems probable that the species is absent from the southern North Sea, for larvae have not been seen in inshore plankton samples from Essex. The absence of Verruca nauplii from hauls at Brighton confirms that the adult cannot be very common in the eastern half of the Channel. At Brixham, Plymouth, and farther west in the Channel (see p. 193) Verruca is often the most abundant cirripede larva in the plankton in spring. 


\section{Hemioniscus balani}

We became interested in the parasitic isopod Hemioniscus balani since there appeared to be some relation between its distribution and abundance and the abundance of its common host, Balanus balanoides. The latter is not, of course, the only host in the Channel since Hemioniscus has been found in Elminius and Balanus improvisus as well as in B. balanus (Perez, I923; Crisp \& Molesworth, I95I). Our records relate to the larger gravid female stage only, as the smaller male stages are often overlooked in the field.

It has already been shown (Southward \& Crisp, I954a) that the incidence of the parasite in the western part of the English side of the Channel in I949-52 was much higher than farther east; the later observations confirm and extend these results. The species was found almost everywhere in the western basin, often at very high percentages of infection, but was very sparse or absent altogether in the eastern basin where the host was more abundant.

Since Hemioniscus occurs in the North Sea, some explanation other than the influence of climate alone must be found for its relative sparsity in the eastern part of the Channel. It is perhaps significant that there was an apparent increase in the rate of infection by Hemioniscus in Devon and Cornwall between I949 and 1952 (Southward \& Crisp, I954a), while the host Balanus balanoides decreased in abundance. More recent observations show a smaller percentage of infection in the following years, coincident with a general resurgence of the host (Southward \& Crisp, 1956).

Just as a change in average temperature may alter the balance between competing species such as Chthamalus stellatus and Balanus balanoides, it may influence a host-parasite relationship. On this theory we have only to postulate that Hemioniscus passes through its life cycle more quickly at higher temperatures, Balanus balanoides being limited in its reproduction to a single annual cycle. Further work is clearly necessary before a definite conclusion can be reached on the dynamics of the relationship between Hemioniscus and its hosts.

\section{Patella vulgata}

The common limpet, Patella vulgata, was found on all solid substrata throughout the channel. On the English side it was the only limpet present east of the Isle of Wight, as reported by Evans (I953).

\section{Patella depressa}

Patella depressa ( $=P$. intermedia) is confined to the western half of the Channel. The eastern limits are at Ventnor and Culver Cliff (Fischer-Piette, I936) on the English side, and Barfleur on the French side. At these stations the range of the species ends abruptly, without undergoing any gradual 
diminution in abundance such as occurs with other animals. At most wavebeaten localities in the western basin it constitutes from 1o to $50 \%$, or frequently more, of the limpet population around mid-tide level. It is scarce or absent on part of the west coast of Cotentin, where the rocks seem to be made unsuitable for limpets by sand scour. On both sides of the Channel it is found in less abundance at the extreme western end. It is absent from the Isles of Scilly, rare in Ushant (Fischer-Piette, 1936), and the abundance on the open coast does not exceed $50 \%$ at any place west of Plymouth. In Finistère our records differ from those of Fischer-Piette (1936) in showing that the species is not entirely absent from Tremazan. A few specimens were found in a limited region towards low water, but the shore appeared generally unsuitable to limpets and barnacles, possibly because of the dense algal growths. At other open coast stations farther east $P$. depressa constituted more than half the limpet population at some levels.

On extremely wave-beaten rocks the limpet population tends to be dominated by $P$. aspera, which seems more tolerant of excessive wave-action or wetting. For example, on the Eddystone rocks off Plymouth the larger limpets are almost all $P$. aspera; $P$. depressa has not been found and $P$. vulgata is represented only by smaller specimens towards the upper midlittoral. At Shipman Head, Bryher, Scilly, over $90 \%$ of the limpets below H.w.N. were $P$. aspera. These effects of wave-action may explain the reduced numbers of $P$. depressa at some of the more western stations, but larval dispersal may also be involved (see p. I94).

\section{Patella aspera}

The distribution of Patella aspera corresponds closely with that of $P$. depressa, and there is a similar sharp cut-off at the identical stations which mark the eastern limits of the species. P. aspera is abundant at most exposed sites in the western basin. We could not detect any general trends in distribution except that the species was scarce on the coast of Cotentin where sand scour is severe.

It must be noted that the agreement in distribution of $P$. depress $a$ and $P$. aspera does not hold good outside the Channel. $P$. aspera extends up the west coast of Britain, and penetrates southward into the North Sea on the east coast of England (evidence to be published later), while $P$. depress $a$ has its northern limit in Anglesey (Crisp \& Knight-Jones, 1955) and is absent from Ireland (Southward \& Crisp, 1954b).

\section{Monodonta lineata}

Monodonta lineata is the most conspicuous of the top-shells, since it is common at the upper limit of the midlittoral zone and can be found in the open on bare rock. Like the other top-shells, however, the greatest numbers are found on partly sheltered shores of boulders or broken rock, and it is less 
common on steep slopes (see Southward \& Crisp, 1954b). Monodonta is abundant throughout most of the western half of the Channel, but extends considerably farther east on the French coast. On the English side the limit

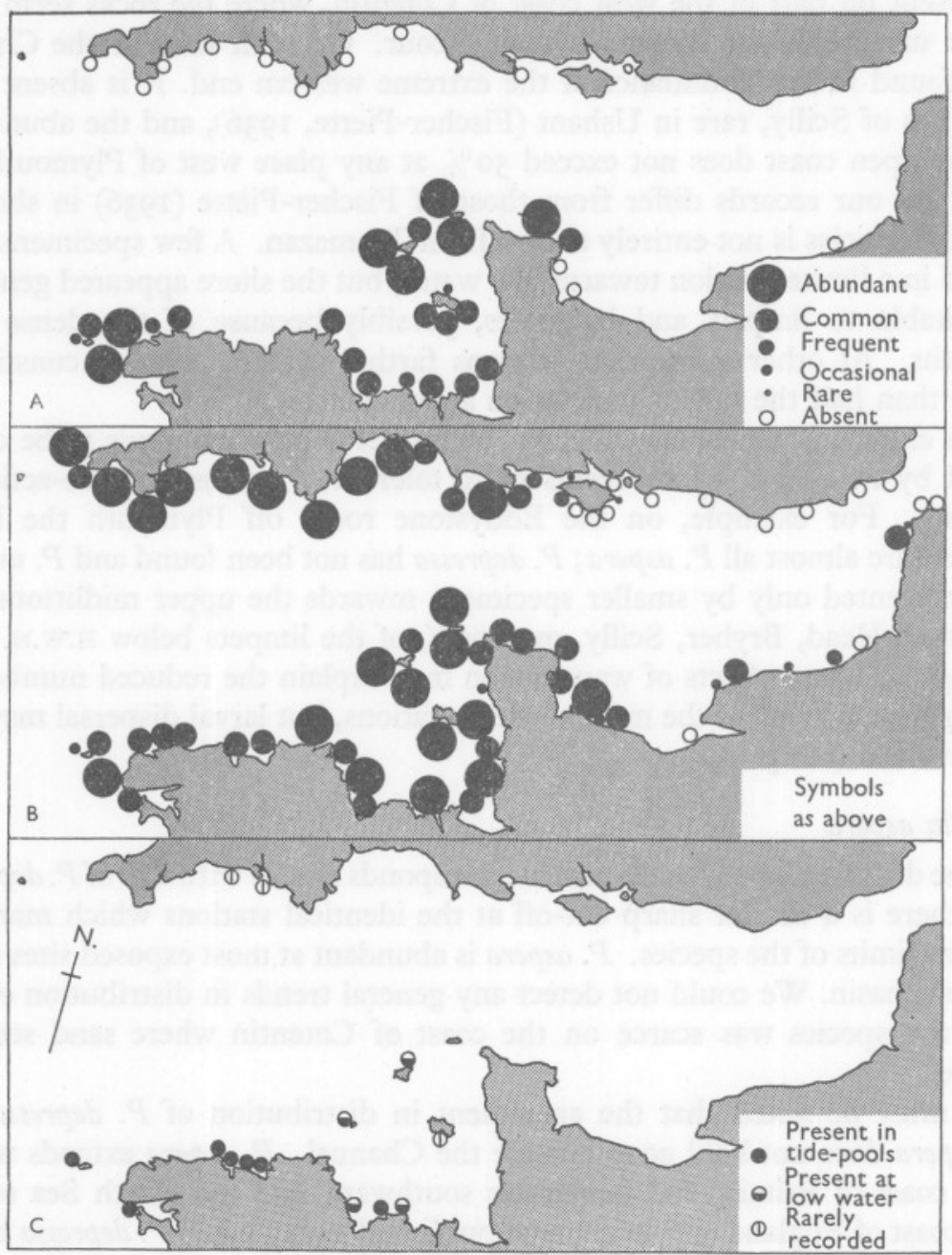

Fig. 3. Distribution of some representative species in the Channel. A, confined exclusively to the French side of the western basin; Gibbula pennant $i$; B, quite common along the whole French coast, but confined to the western basin on the English side; G. umbilicalis; c, confined to the western basin, but not at all common in the Channel, and rarely found on the English side; Paracentrotus lividus.

is at Lyme Regis; on the French side it is present in small numbers east of the Cotentin peninsula, but is absent from most of the Normandy coast. The boundaries of this species imply that it is limited by factors other than the 
configuration of the shore, for many apparently suitable shores are found to the east of its range. For example the Dorset coast between Weymouth and Swanage, and the Normandy coast east of Arromanches, both offer very suitable habitats for top-shells if the abundance there of Gibbula umbilicalis is taken as a guide. We have unsuccessfully searched the Dorset area several times, since there are old records (Mansell-Pleydell, I898) of the occurrence of Monodonta there. It seems probable that the records are based on casual findings of dead shells; the finding of a 'recently vacated' dead shell at Whitstable, Kent (el Maghraby \& Perkins, 1956) shows how misleading such records may be.

\section{Gibbula umbilicalis}

The distribution of Gibbula umbilicalis follows the pattern of that of Monodonta, and although it penetrates somewhat farther east than the latter on both sides of the Channel, there is again a considerable difference between the English and French sides (Fig. 3, p. I76). The most easterly occurrence of Gibbula umbilicalis on the English coast is at Bembridge, while on the French side it occurs as far as Calais. The areas where the species was not found on the French coast, around Le Havre and Le Tréport, are rather unfavourable to top-shells, the few rocks being separated by wide stretches of sandy beach. On the English coast the absence east of the Isle of Wight cannot be attributed entirely to the absence of suitable shores, for there are apparently suitable habitats at Seaford, Brighton and near Beachy Head.

\section{Gibbula pennanti}

The validity of the species Gibbula pennanti, noted as an unnamed variety of G. umbilicalis by Forbes \& Hanley (1853), has been established by Gaillard (1954). We ourselves did not learn the species until the later part of the survey. For this reason our maps are not as complete as could be desired (Fig. 3A). The adults can be separated easily from G. umbilicalis by the closure of the umbilicus and, once learnt, the two are usually distinguishable on shell pattern alone. The uninitiated would be easily misled, for although G. pennanti may be commoner at low water in some places, in localities where it is abundant it tends to occur over most of the midlittoral zone and may replace G. umbilicalis as the most abundant top-shell. Unlike G. umbilicalis, however, $G$. pennanti is confined to the French side of the western half of the Channel. It was found at most stations on the Cotentin peninsula, the Gulf of St Malo, and the Brittany coast, and was common in the Channel Islands, especially in Alderney and Guernsey, but was absent east of Barfleur. Careful searches in the south-west of England, in places where the habitat appeared to be essentially similar to that in which the species is found in France, have failed to disclose a single specimen. 


\section{Gibbula cineraria}

The top-shell commonly found at low water, Gibbula cineraria, was found throughout the Channel. Although it favours broken rocky shores like other top-shells, the species is much less sensitive to the presence of sand, and may sometimes be common in predominantly sandy places. Unlike the other species of Gibbula discussed above, it is quite common infralittorally, especially among algae.

\section{Littorina species}

The common small periwinkle, Littorina saxatilis, is abundant throughout the Channel. It seems very tolerant of scouring and of low salinity. L. obtusata is also common everywhere where fucoids are plentiful.

The edible winkle, $L$. littorea, is present throughout the Channel on the more sheltered shores. It is intolerant of wave-action, and is scarce at the western extremities of both sides of the Channel, and very rare in the outer Channel Islands. We did not find it in the Isles of Scilly, but it was recorded there by Clark (1906), and Mr G. M. Spooner tells us that he found two specimens in 1936.

L. neritoides is abundant on exposed shores throughout the western half of the Channel. On the English side it is present in the Isle of Wight, where the eastern limit is Sandown. On the French coast it penetrates somewhat farther into the eastern basin; it was present in small numbers on the Normandy coast east of Cotentin, and two specimens were collected at Calais.

\section{Paracentrotus lividus}

The sea-urchin, Paracentrotus lividus, which is such a noticeable feature of intertidal pools on the Atlantic coasts of Ireland and France, is much rarer in the Channel, where it is often confined to extreme low-water mark or the infralittoral zone. For this reason we have few positive records, and have relied on earlier observations to compile Fig. 3C. Paracentrotus can be regarded as virtually absent on the English side, specimens having been found only occasionally at Looe and Wembury (Marine Biological Association, I957; personal recollections of the Plymouth Laboratory staff; preserved material in the faunal collection at Plymouth). On the French side our observations confirm that the species is common only in the neighbourhood of Roscoff (Station Biologique de Roscoff, I95 I $a$ ) where it is present in pools towards low water. It is less common in the Bay of St Brieuc, at the Roches Douvres and in Guernsey (Koehler, I884; Fischer, I928). No specimens were found during our survey in the extreme north-west of Brittany, but observations were not made on the more exposed islands offshore where Paracentrotus may be more common, as it is in Ushant. 


\section{Balanus balanus}

OTHER ANIMALS

Balanus balanus $(=B$. porcatus $)$ is not common intertidally, but its distribution has always interested us, as it is a species of markedly northern character. It is present on the shore, at extreme low water, in Anglesey and the Isle of $\mathrm{Man}$, and there are recent records of its occurrence at low water, or just within the infralittoral zone in south-west Ireland (Lilly, Sloane, Bassindale, Ebling \& Kitching, 1953). It has been found on test panels from Milford Haven, and has been recorded by Bassindale (I94I) in other parts of the Bristol Channel. The species seems to be common in the North Sea, but we have been unable to confirm any of the records of its occurrence in the Channel. It has not been seen on the shore, and has never been found on dredged material brought into Plymouth or Brixham. There exist specimens in the Jeffreys collection, now in the U.S. National Museum, labelled as from Exmouth (Pilsbry, I9I6). The authenticity of some of the Jeffreys material is doubtful, however, since the collection includes specimens of $B$. perforatus labelled as from Irish and Scottish localities where the species does not occur (Norris \& Crisp, I953; Southward \& Crisp, 1954b). The most reasonable view of these discrepancies in the Jeffreys collection is that some of the labels have been exchanged.

At the moment we conclude from the limited evidence that B. balanus is absent from the western half of the Channel and scarce or absent in the eastern half.

\section{Haliotis tuberculata}

The ormer, Haliotis tuberculata, found mainly at extreme low water or infralittorally, is restricted entirely to the western half of the French side of the Channel, where the limits are Alderney and Cherbourg (Wegmann, I884; Sinel, 1906; Stephenson, 1924; Crofts, 1929; Tomlin, 1937; Station Biologique de Roscoff, I95I $b$ ). We have few personal records, but local collectors confirmed that the species is still quite abundant in Guernsey and Alderney, where it may be commoner than in Jersey, and in north Brittany.

\section{Gibbula magus}

The top-shell Gibbula magus is predominantly infralittoral, but is sometimes common at extreme low-water mark in the Channel. Its distribution intertidally appears to follow the trend of the other top-shells of southern character, for the species is much more frequent on the French side. It is common on sandy shores. We found it in some number on the Cotentin peninsula, as far east as Grandcamp, and it appears to be abundant around Roscoff (Station Biologique de Roscoff, I95 I b). G. magus sometimes occurs intertidally near Plymouth (Marine Biological Association, 1957) but numbers approaching those found on the French coast have been encountered only in the Isles of Scilly. 


\section{Calliostoma zizyphinum}

A further top-shell, Calliostoma zizyphinum, has been included in the detailed table (Table 7, Appendix), but the distribution is not clear. Since the species can occur infralittorally only positive records have been noted. Calliostoma is present throughout the Channel, and has been recorded from the vicinity of Ramsgate (Woodward, I880). That more records from the western basin than the eastern basin are included in the table may be due to the greater amount of rocky shores available in the west, and it is not possible to be sure of any trends in distribution.

\section{PLANTS}

Only the commoner species of large Phaeophyceae could be investigated (Table I, p. I59). No doubt the other classes of algae have species with corresponding types of distribution (cf. Fischer-Piette, 1936).

\section{Laminaria ochroleuca}

Probably the most southern in distribution of the laminarians, L. ochroleuca has been recognized in the Channel only in more recent years. There seems good evidence for believing that it has increased its range and abundance in the Channel (Parke, I948). It is now common in south-west Cornwall and around Plymouth, and extends as far east as the Salcombe estuary (Spooner, I950), but is apparently absent from Torbay and farther east (personal communications, Mr G. M. Spooner). On the French side the distribution corresponds with that of the southern types of animals. It is abundant at the western end, and has its eastern limit about Alderney and Barfleur, but is apparently absent in the Gulf of St Malo, Jersey, Guernsey and most of Cotentin (Hamel, I93I-39; Lami, I943, I954; Station Biologique de Roscoff, 1954).

\section{Laminaria spp.}

The three other species of Laminaria present in the Channel, L. digitata, L. hyperborea and L. saccharina, occur throughout. L. digitata and L. hyperborea, which grow best on firm substrata where there is some exposure to wave-action, may be less common in the eastern basin.

\section{Saccorhiza polysichides}

The laminarian Saccorhiza polysichides is of relatively southern character; like Laminaria ochroleuca it seems to be absent from the eastern half of the Channel. On the French side the eastern limit is just north of Barfleur (Hamel, I93I-39). 


\section{Alaria esculenta}

The only laminarian to favour very wave-beaten sites, Alaria esculenta, is found exclusively in the western basin of the Channel. On the French side it occurs as far east as Alderney and Cherbourg (Fischer-Piette, 1936; Hamel, I93I-39). We were unable to visit many of the really exposed sites that the species favours, but have confirmed that it is abundant in Alderney. On the English side Alaria does not seem to penetrate as far east. We have found the species as far east as Portland Bill, but it is not common to the east of Start Pt. Its southern limit is just south of the entrance to the Channel (Dizerbo, I947).

\section{Ascophyllum nodosum}

Ascophyllum nodosum is present throughout the Channel, but appears to be commoner in the western half (Hamel, I93I-39), especially in estuaries and sheltered bays.

\section{Fucus and Pelvetia}

The fucoids Fucus spiralis, F. vesiculosus, F. serratus and Pelvetia canaliculata are present throughout the Channel.

\section{Himanthalia elongata}

We have confirmed that Himanthalia elongata is confined to the western half of the Channel (Fischer-Piette, 1936; Hamel, 193I-39). The eastern limits are Peveril Pt. and Barfleur, but the species is absent from the inner parts of Lyme Bay and the Gulf of St Malo. This distribution has been discussed in some detail by Fischer-Piette (1936).

\section{Bifurcaria rotunda}

There is little to add to previous accounts of the distribution of Bifurcaria rotunda. It is present in pools at most exposed sites on the English coast as far east as Start Pt.; it is not now absent at Wembury ('Blackstone Pt.') as stated by Fischer-Piette (1936). On the French side it is quite abundant in the two outer Channel Islands, Alderney and Guernsey, and on the north coast of Cotentin, but does not occur east of Barfleur. It is often found as a distinct zone at the upper limit of Himanthalia in France and the Channel Islands, but we have not observed this form in England, although it was noted at a few stations by Fischer-Piette.

\section{GENERAL TRENDS OF THE DISTRIBUTIONS}

\section{East-west trends}

There is a clearly marked east-to-west trend in the distributions of many of the animals and plants which have been described. In nearly all such species not only is the general trend from east to west the same, but the range 
and even the detailed features show that a remarkable similarity exists between the British and French coasts. For example, Balanus balanoides becomes gradually less common west of the Cherbourg peninsula and of the Isle of Wight as Chthamalus stellatus increases, and markedly less common west of Start Point and Sillon de Talbert. The eastern limits on the two sides of the Channel of Patella intermedia, P. aspera, Anemonia sulcata and Balanus perforatus are almost identical. Perhaps the most striking feature of the general similarity between the two coasts is the sharp faunal and floral discontinuity existing on both sides at the junction of the eastern and western basins. On the British side the limits of Chthamalus stellatus, Balanus perforatus, Littorina neritoides, Gibbula umbilicalis, Patella intermedia, and P. aspera occur at or very close to the Isle of Wight, the limits of Monodonta lineata and Himanthalia somewhat farther to the west, while Anemonia sulcata, though very common in parts of the Isle of Wight, has been found at only one station farther east. The critical nature of these limits is indicated in Fig. 4. A similar critical change occurs at Alderney and on the Cotentin peninsula, where Chthamalus stellatus, Balanus perforatus, Patella depressa, P. aspera, Paracentrotus lividus, Haliotis tuberculata, Laminaria ochroleuca, Saccorhiza polysichides, Alaria esculenta, Himanthalia elongata and Bifurcaria rotunda all have their eastern limits, although some species, e.g. Monodonta, Littorina neritoides and Anemonia extend a little to the east (Fig. 5).

These sharp biological limits midway along the Channel coincide with the topographical limits separating the two basins. Thus the western basin has a rich fauna including many Atlantic and Lusitanian-Mediterranean forms together with Boreal and Celtic species, while the eastern basin has a depleted fauna from which most of the southern elements are missing.

\section{North-south differences}

Differences between distributions of animals on the north and south coasts of the Channel are less conspicuous than those between the east and west basins. The differences that exist are due to the presence of more southern forms on the French coast. Gibbula umbilicalis and Littorina neritoides have a greater range eastwards on the French side: other forms which are generally more abundant are Bifurcaria tuberculata, Laminaria ochroleuca and Gibbula magus. Several species are found exclusively or almost exclusively on the French side, such as $G$. pennanti, Haliotis, Paracentrotus, and also species not included in the present survey such as Pollicipes cornucopiae ${ }^{1}$ and possibly Pachygrapsus marmoratus, which was at one time present in the Roscoff area. The only species which appears to be more abundant on the British coast is Chthamalus stellatus. It is interesting to note that this species can occur very high up in the intertidal zone, while those forms restricted to the French side are mainly found towards low-water mark.

\footnotetext{
1 There is a single record of Pollicipes from Land's End (specimens in British Museum).
} 


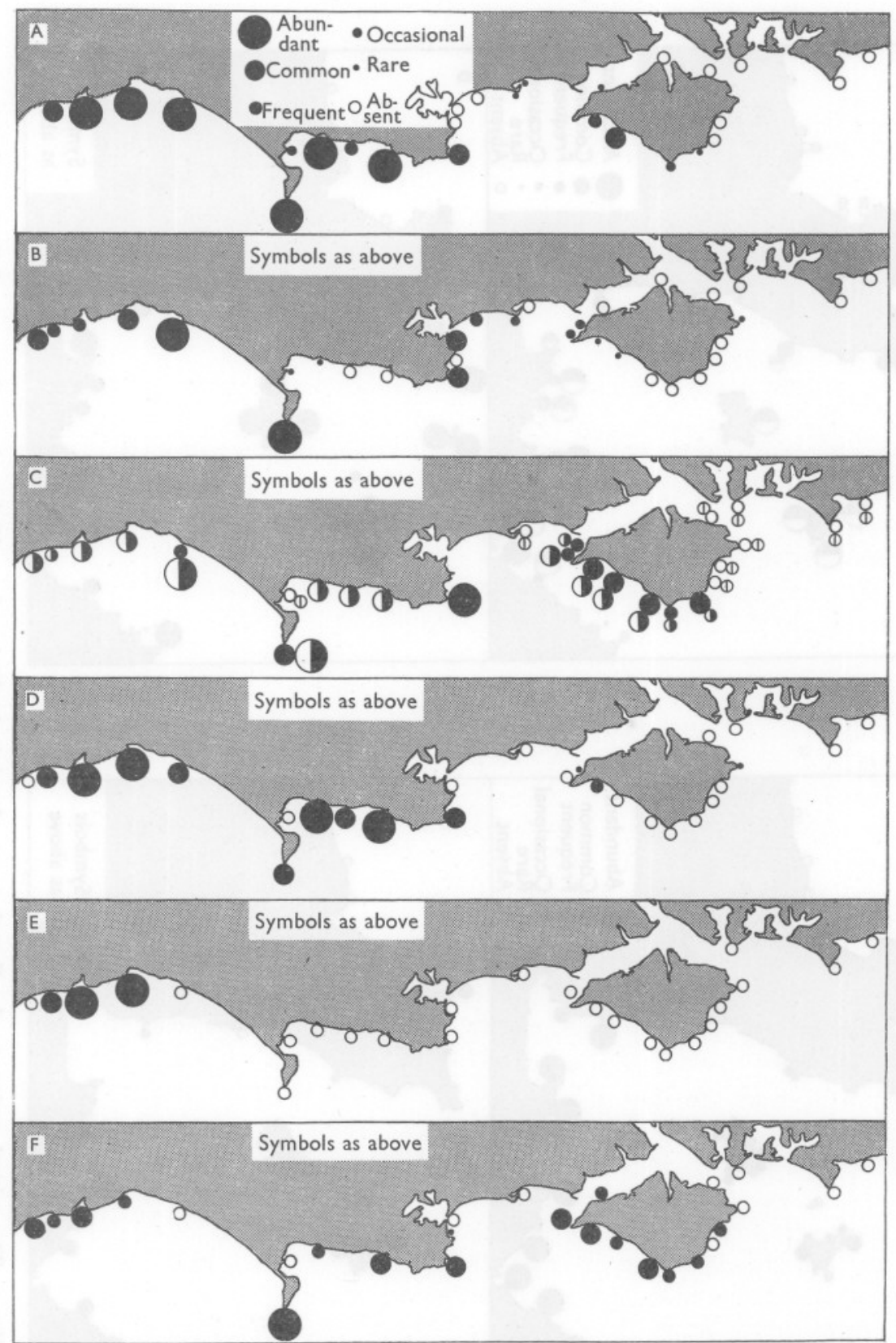

Fig. 4. The critical region on the English coast where many of the southern forms have their eastern limits. A, Chthamalus stellatus; B, Balanus perforatus; c, Patella aspera and $P$. depressa, the latter shown by half-black or barred symbols; D, Gibbula umbilicalis; E, Monodonta lineata; $\mathrm{F}$, Littorina neritoides. 


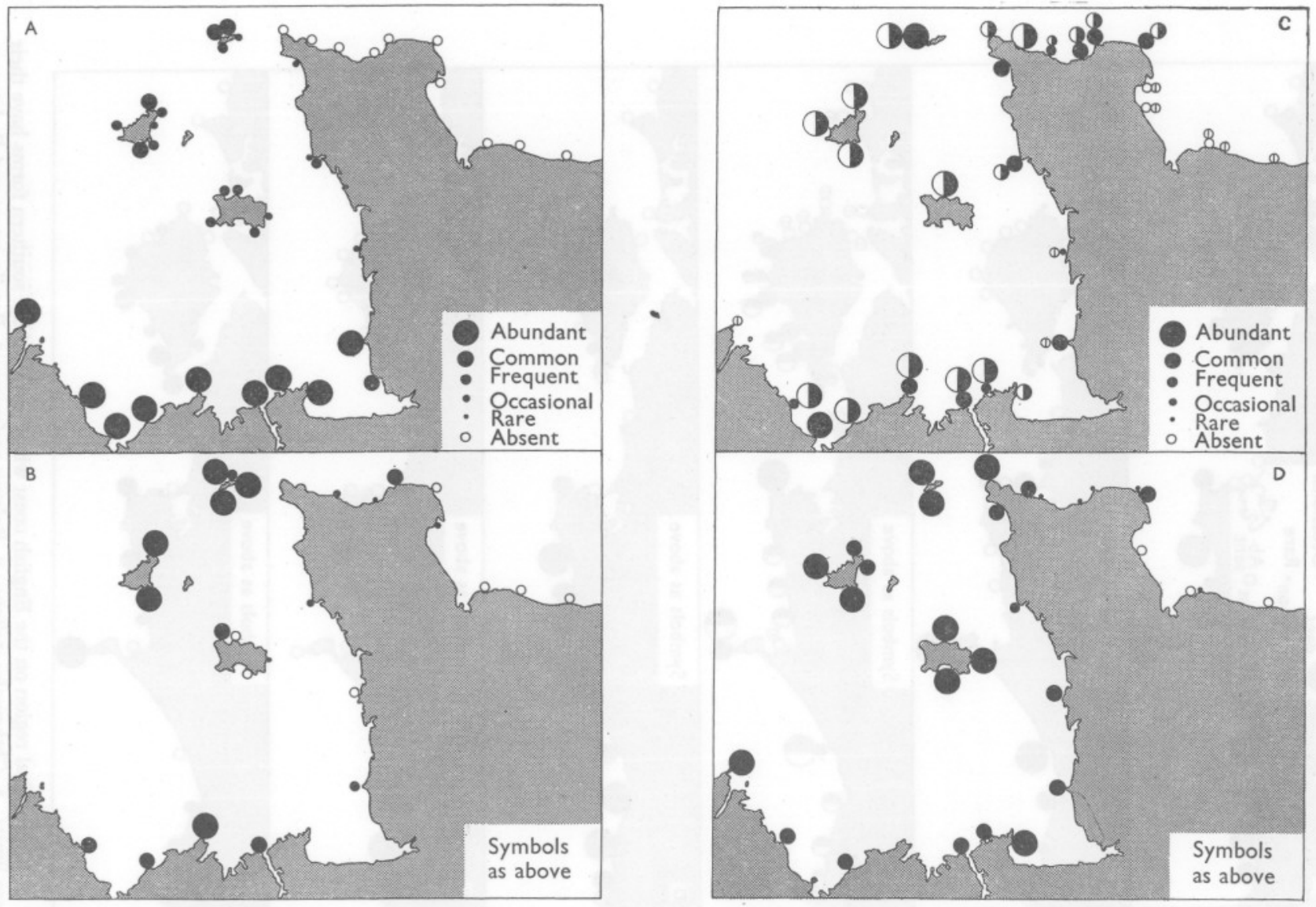

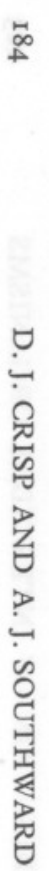

Fig. 5. The critical region on the French coast, showing the limits of: A, Chthamalus stellatus; B, Balanus perforatus; c, Patella aspera and P. depressa; and D, Monodonta lineata. The half-black or barred symbols refer to Patella depressa. 


\section{RELATION BETWEEN DISTRIBUTIONS AND ENVIRONMENTAL FACTORS}

We have already described the major environmental variables found in the Channel. In this section they are discussed as controlling influences on the distribution of the organisms.

The animals and plants which share the main trend in distribution from east to west are varied in many respects. First, their requirements differ in regard to exposure. Some, such as Littorina neritoides, Chthamalus stellatus, Paracentrotus lividus, Patella aspera, and Alaria esculenta, grow best in rocky wave-beaten situations, while others, such as top-shells Monodonta lineata, Gibbula umbilicalis, G. pennanti and G. magus occur predominantly in some degree of shelter. The greater expanse of rocky shore, and the heavier swell at the western end of the Channel cannot therefore be the only, nor indeed the main factors. At least one species not included in our survey, which requires the proximity of a sandy or gravelly environment, Sabellaria alveolata, is abundant in many areas at the western part of the Channel and is replaced by $S$. spinulosa to the east.

Secondly, they differ in their relation to tide level. Some of those confined to the western half of the Channel, such as Anemonia sulcata, Gibbula magus, Paracentrotus lividus and Bifurcaria tuberculata, are found mainly at the lower levels or in pools, while others such as Chthamalus stellatus and Littorina neritoides, are found high up the shore. It is not possible therefore to attribute the general trend to differences in the tidal regime such as the occurrence of equinoctial spring tides at midday in the western basin and at morning and evening in the eastern basin.

Thirdly they differ in their nutrition. The plants are, of course, autotrophic. Many of the animals, such as the limpets Patella aspera and P. depressa, the periwinkle L. neritoides, the top-shells Monodonta lineata, Gibbula umbilicalis and G. pennanti, and the urchin Paracentrotus lividus, are surface scrapers, though their nourishment must differ considerably with their tidal zonation and particular habitat. Others, such as the barnacles, can feed on suspended matter including a wide range of particle size (Southward, 1955a). Anemonia sulcata is a macrophagous carnivore, and Hemioniscus balani a parasite. The distributions cannot therefore be attributed to a greater abundance of food organisms in any particular habitat.

Lastly the organisms showing the east-west trend differ in their life histories. The great majority have planktonic stages, but there are without doubt great differences between them in the periods of their development in the sea, although the precise duration of many is not known. All the barnacles, Paracentrotus, and probably most of the littorinids have relatively long planktonic phases, while the limpets take only a few days to metamorphose (Lebour, I937; Thorson, I946; Dodd, 1957). The anemones are viviparous, 
while some of the algae have sporophyte generations which alternate with a small gametophyte. It follows that biological factors present in the sea which influence larval development cannot exercise an important influence on the distributions as a whole.

\section{Effect of temperature}

Of the few environmental factors which can be considered as having possible influences on such widely varying organisms, temperature, which may affect all stages of the life history, is probably the most important. Since the western end of the Channel is warmer on average and certainly less severely cold in winter, the species which are plentiful there should be those which are either unable to compete successfully with cold hardy forms or which suffer directly from exposure to the cold; that is forms with a southern or Lusitanian distribution. Conversely, since the eastern end of the Channel is much colder in winter, the forms predominating there must be tolerant of cold conditions. Table I (p. 159), which summarizes the known distributions and other relevant details of the species which have been studied, shows that the majority of the forms confined to the western basin of the Channel are in fact those of southern distribution. Of the species whose distribution extends well to the north of the British Isles, the majority are found in similar abundance in both basins, though Arctic forms such as Balanus balanoides are less common in the extreme west. The Arctic form Alaria esculenta is exceptional in occurring only in the western part of the Channel. It is possibly so dependent upon wave-beaten sites that it is excluded from the eastern basin, even though it has its southern limits just south of the Channel.

The differences between the north and south coasts of the Channel may also be attributed to temperature differences. The sea temperature is higher in winter on the French side of the western basin, and in summer is distinctly higher in the Gulf of St Malo and the Baie de Seine. Thus a number of animals and plants of southern origin penetrate for varying distances along this coast, although they are not represented, or are very sparse, on the coasts of South Devon and Cornwall. Others are able to extend farther eastwards on the French side than on the English side (see above).

There are certain objections, however, which might be raised against the view that the temperature gradient is the predominant factor influencing distributions in the English Channel.

The first difficulty arises from the generally accepted view, put forward by Apellöf (I912), Orton (1920), and Runnström (1929), that marine organisms are restricted primarily by the temperature prevailing during the breeding season, for most animals can live at considerably greater extremes of temperature than those which are tolerated during the reproductive period. Thus, for example, many animals found near their northern limits in south-west Britain breed only for a short period in the summer months, so that their fecundity is 
progressively reduced with fall in summer temperature. There is, moreover, little doubt that land-locked areas, having increased summer temperatures, offer especially favourable environments (Southward \& Crisp, 1954b). Yet, as will be seen by comparing the summer and winter isotherms with the general trend of the distribution maps, the correlation between distribution and temperature applies not to the maximum reached in summer, which would be thought to be critical for reproduction, but rather to the winter minima. Winter conditions can have little relevance to the reproductive state or to the larval stages, for as shown in Table I all but three southern forms breed in summer. The difficulty cannot satisfactorily be resolved by assuming that winter temperatures in the eastern half of the Channel are lethal to the adults of these species, for there is no evidence of such mortality. Experimentally it has been demonstrated that some of the southern forms are killed at temperatures that are not uncommon on the land at the eastern end of the Channel. But, as the accompanying paper on this subject shows (Southward, 1958), the more extreme values of low air temperature recorded will be rarely experienced by the animals on the shore. Possibly the less extreme temperatures that are found on the shore might be shown to have debilitating effects in long-term experiments, but against this is the fact that one species at least (Chthamalus stellatus) can survive transplantation to the north and east of Britain, overwinter, and produce nauplii the following summer (Crisp, I950). If mortality occurred as a result of cold, species which extend throughout the greater part of the intertidal range in south Devon, such as Chthamalus stellatus and Littorina neritoides, would be expected to be killed predominantly at their upper limits where the duration of frost exposure is greater. In fact, however, these two species are absent from the lower levels in cooler localities and at their extreme eastern limits are found only high up the shore.

These difficulties arise through seeking a temperature-vulnerable phase in the life history, probably an unwarranted simplification. All stages in the life history are influenced by temperature. Not only must the adults attain a breeding condition and the larvae develop successfully, but the post-larvae and young adults of most southern forms must also survive and grow sufficiently during the coldest part of the year. Therefore an equably warm environment such as occurs in the western half of the Channel may be better for southern forms than one of extremes, despite possibly higher temperatures at the breeding season. There may, in fact, be no direct influence of temperature at all. If the survival of the species depends upon its rate of growth or feeding in competition with other forms, temperature may operate decisively on this competition well above the level at which it would be directly lethal (cf. Southward, 1955 $b, 1957$ ). We have described elsewhere how the generally warmer conditions in south-west Britain may favour a southern form Chthamalus stellatus, while towards the north and east it is displaced by Balanus 
balanoides, a northern form occupying a similar niche (Southward \& Crisp, 1956). Barnes (1956) has evidently reached the same general conclusion. The evidence therefore suggests that the presence of some, perhaps the majority, of the southern forms in the western half of the Channel but not farther east is not simply because they can survive there during the milder winter, but rather because the temperature is favourable to them for a sufficiently long period during the year. That the recent climatic amelioration seems to have been accompanied in the Channel by an increase in range and abundance of at least three southern species tends to support this view. Further, the hypothesis that temperature influences animals and plants throughout the year, and during all stages in their life history, is necessary to explain certain minor trends in distribution as, for example, the variation in the abundance of Chthamalus stellatus and Balanus perforatus in the Gulf of St Malo (p. I7I). In this area there is considerable variation from place to place in the range of temperature throughout the year, but it must on average be sufficiently high for southern forms. The abundance of these two southern species in the two outer islands, Alderney and Guernsey, can be attributed to the more equable temperatures there during the cooler part of the year; this probably assists them in competition with the northern species, B. balanoides, which is somewhat less abundant than it is in Jersey and other parts of the Gulf. However, the same two southern species are also abundant on the southern shores of the Gulf; their abundance there must be attributed to the beneficial effects of heating-up of the shore and shallow water during the summer, and its influence on breeding and larval output (cf. Southward \& Crisp, 1954b). The beneficial effect must be so great that it enables the species to overcome the difficulties imposed by the very much colder conditions during the winter. Jersey lies between the two areas in temperature regime; its shores are cooler in summer than those of the mainland, and it is colder in winter than the outer islands. Presumably the summer temperature is not high enough to allow sufficient increase in breeding activity to compensate for conditions during the rest of the year.

\section{Critical limits}

There are other aspects of distribution that cannot be explained by the temperature hypothesis alone, notably the existence of sharp discontinuities affecting several species together. These discontinuities are found at the Isle of Wight and the north coast of Cotentin, at the region of separation of the eastern and western basins. Examples of similar critical limits are found in Anglesey (Crisp \& Knight-Jones, 1955).

The critical limits in the Channel do not coincide with closely approximating isotherms (Figs. I, 4, 5). If temperature alone were controlling distribution of the southern species the limits of different species would be expected to lie at a series of geographically separated regions, the position of 
each limit being related to the temperature tolerance of the species in its natural habitat. It is very unlikely that the tolerance limits would then be nearly identical for so many of the species studied. Therefore these sharp faunistic limits point to some factor additional to temperature acting as a barrier.

\section{Effect of substratum}

The shores of the eastern basin of the Channel differ from those farther west (p. I64), the infrequent outcrops of harder rock and the prevalence of beaches of scouring material making conditions less suitable for rock-living organisms. These conditions influence adversely all such organisms, but any which are near extinction through other factors, such as temperature, may be unable to extend beyond the point where suitable rock becomes scarce. That this is so is strongly suggested by the fact that the fauna of the eastern section of the Channel is an impoverished one. All the species represented there, so far as we know, are found in the western basin, though some in less abundance. Many species found in the west are, however, absent from the eastern part of the Channel. These species are mainly, but not all, of southern origin. Similarly, many species of algae, for example Bifurcaria, Himanthalia, Saccorhiza and Alaria, the latter a northern form, are absent. This poverty of algae must surely be related in part to lack of sufficient rock substratum, to opacity of the water, and to the damage due to scour. The relative lack of rocky substrata and the extent of the scouring that may occur in the eastern basin probably contributes to the absence of the more southern barnacles, and to the scarcity or absence of forms such as Patella aspera and Littorina neritoides, which can live under the cold conditions of the Yorkshire coast. Thus, it may be that to forms approaching their limit of tolerance of other conditions, including temperature, a change in the nature of the shore may present a simultaneous physical barrier.

However, although the critical faunistic limits correspond roughly with the beginning of extensive areas of sand and shingle, certain of the species terminate to the west of the point where the shore character changes. For example, Chthamalus is not found on the north coast of Cotentin, where ample rock is available, while apparently suitable beaches of large boulders occur in Dorset and Normandy eastwards of the limits of Monodonta. In the Isle of Wight several of the species studied do not penetrate beyond the southern tip, though apparently suitable reefs exist at the eastern end of the island. Populations growing near the eastern boundary of a rocky shore can clearly be recruited only from the west, but this should not in theory reduce the population density below about half that of regions where recruitment can occur from both directions, assuming even dispersal of larvae.

There are two other factors which may account for the position of these critical faunistic limits more precisely: aspect and dispersal. 


\section{Aspect}

The need to shelter half-hardy garden plants from north and east winds is well known. The same is likely to hold for the sessile or nearly sessile plants and animals of the intertidal zone. Indeed the effect is probably more pronounced on the shore than it is inland because the cooling effect of strong cold winds from east or north will be enhanced by evaporation as the sea ebbs and the animals are exposed to the air. On a south- or west-facing shore the strongest winds will be associated with mild weather, but on a north-, and especially on an east-facing, shore the strongest onshore winds will be from a cold quarter, so that the greatest cooling by evaporation will occur simultaneously with low air temperature. North-facing shores will also receive less warmth on account of the lower angle of incidence of the sun; they may be almost without sunlight in winter if the slope is steep. The distribution maps show that many of the limits of southern forms coincide with a change in aspect of the coast. Chthamalus stellatus, Balanus perforatus, Gibbula umbilicalis, Littorina neritoides and Patella intermedia all disappear near St Catherine's Pt., Isle of Wight, where the aspect of the coast changes from south-west to south-east; on the Cherbourg peninsula Chthamalus disappears near Cap la Hague, where the aspect changes from west to north, while Patella depressa, P. aspera, Himanthalia, Bifurcaria and Saccorhiza, and to a large extent Balanus perforatus disappear around Barfleur, where the aspect changes from north to east. A notable example of the apparent influence of aspect on a species of northern character is found in west Cornwall (Fig. 6). Here $B$. balanoides is virtually absent from the south coast, rare on the west-facing portion, and abundant on the north-facing region of the coast. Although not shown on the map, the species becomes less common farther east on the north Cornish coast, where it gains a more westerly aspect.

\section{Effects of currents}

Another factor which may cause several species to undergo a sudden change in abundance is the influence of currents on dispersal of the planktonic larvae. Intertidal animals with free-swimming larvae must suffer loss of recruitment whenever the larvae are carried too far out to sea and fail to return to the coast. The amount of loss will depend on how far the tidal or residual currents carry water masses offshore, and will increase with the strength of these currents. When the loss of recruitment becomes critical the species must disappear, for there are usually minimal densities of adults below which the population cannot maintain itself without outside assistance (Crisp, I950; Crisp \& Southward, I953; Crisp, I958: see also Darwin, I872; Andrewartha \& Birch, I954). 


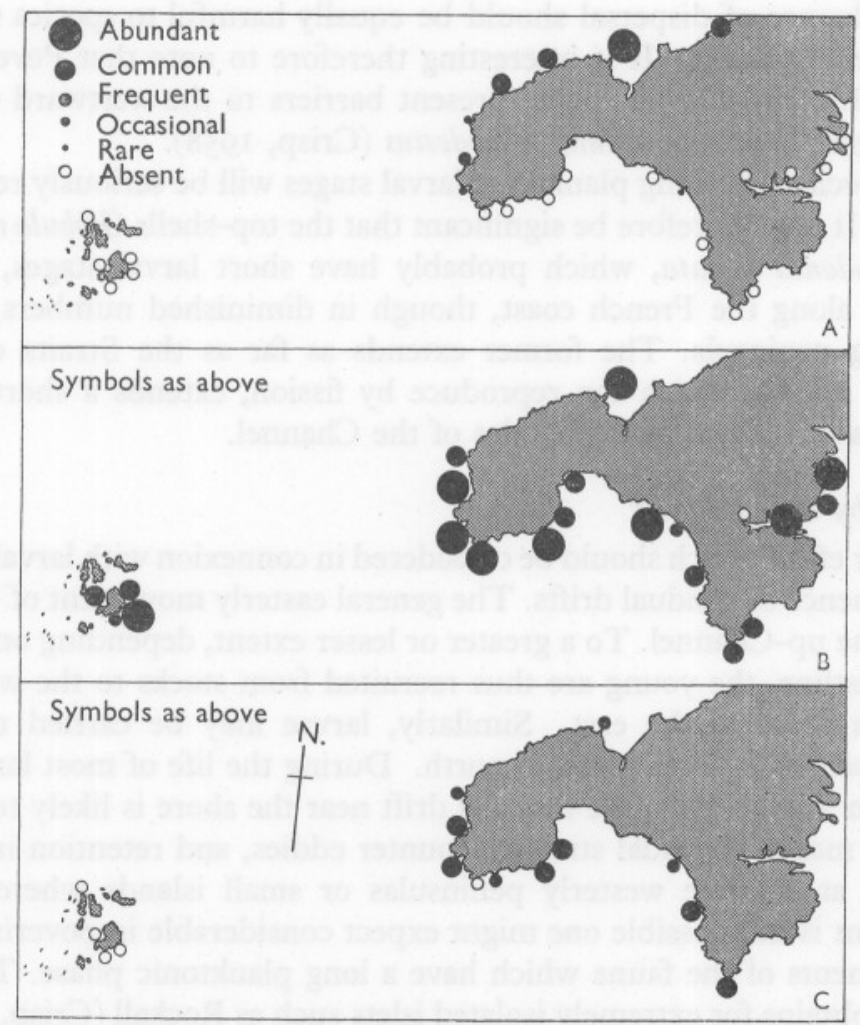

Fig. 6. Part of west Cornwall and the Isles of Scilly, showing the distribution of: A, Balanus balanoides; B, B. perforatus; and c, Patella depressa.

\section{Dispersal by tidal streams}

In the Channel, the main tidal streams are greatest between the two basins (see p. I63), while offshore races with turbulence occur at headlands. Therefore the greatest loss of larvae by dispersal would be anticipated at headlands such as St Catherine's Pt., Portland Bill, and off the points of the Cherbourg peninsula and Alderney. Not only must dispersal be increased in this region, but also the diminished tidal range, especially on the English side, may restrict the available stocks of adults, since these are necessarily confined to a narrower zone on the shore.

Change in aspect and increased dispersal are probably both important in determining faunistic boundaries. The fact that both on the south-facing British shore and on the north-facing French shore many of the critical faunistic limits coincide with headlands lying midway between the two main basins suggests that larval dispersal may be a more important factor than aspect. 
The influence of dispersal should be equally harmful to species spreading from either direction. It is interesting therefore to note that Peveril Point, Portland Bill, and Cap la Hague present barriers to the westward spread of the immigrant barnacle Elminius modestus (Crisp, 1958).

Only species with long planktonic larval stages will be seriously reduced by dispersal. It may therefore be significant that the top-shells Gibbula umbilicalis and Monodonta lineata, which probably have short larval stages, continue eastwards along the French coast, though in diminished numbers, past the Cherbourg peninsula. The former extends as far as the Straits of Dover. Anemonia sulcata, which can reproduce by fission, extends a short distance into the eastern basin on both sides of the Channel.

\section{Dispersal by residual drift}

Another effect which should be considered in connexion with larval dispersal is the influence of residual drifts. The general easterly movement of water will carry larvae up-Channel. To a greater or lesser extent, depending on the form of the coastline, the young are thus recruited from stocks to the west rather than from those to the east. Similarly, larvae may be carried round the Brittany peninsula from south to north. During the life of most larvae (anything from 2 to 30 days) the residual drift near the shore is likely to be small and to be masked by tidal streams, counter eddies, and retention in pockets. However, at extreme westerly peninsulas or small islands where westerly recruitment is not possible one might expect considerable impoverishment of those elements of the fauna which have a long planktonic phase. This effect certainly obtains for extremely isolated islets such as Rockall (Crisp, I956). It is surprising that so little impoverishment occurs at such places as north-west Brittany, Cape Cornwall, Lizard Head, Eddystone Rocks, etc. The presence, for example, of good barnacle settlements in these areas suggests that there are coastal drifts running counter to the main eastward drift, and able to carry larvae round these headlands. Certain species, however, become sparse at the western extremity both of Brittany and Cornwall, and more particularly in Ushant and the Scilly Isles, notably Balanus balanoides (absent from Scilly), B. perforatus (not at all abundant on Ushant, Scilly, or the Lizard), Patella depressa (absent from Scilly, rare on Ushant, not abundant in Finistère or west Cornwall), Littorina littorea (rare in Scilly and Ushant), and Mytilus (not studied in this survey, but known to be uncommon in Scilly and Ushant). Balanus balanoides and Littorina littorea are relatively northern in distribution and may be affected by the warmer maritime conditions in these areas, but this is not likely for the other species.

One of us (A.J.S.) has recently obtained further evidence relating to larval dispersal off west Cornwall and the Isles of Scilly, where a series of plankton samples were taken over a limited period in March 1956 (Fig. 7). The samples were taken for the specific purpose of determining whether the larvae of 
Balanus balanoides were present off Scilly during the short breeding period of the species. However, the distributions of the larvae of other species of barnacles found in the samples proved to be pertinent to the present work and are also illustrated. The boundaries of both Verruca stroemia and Balanus

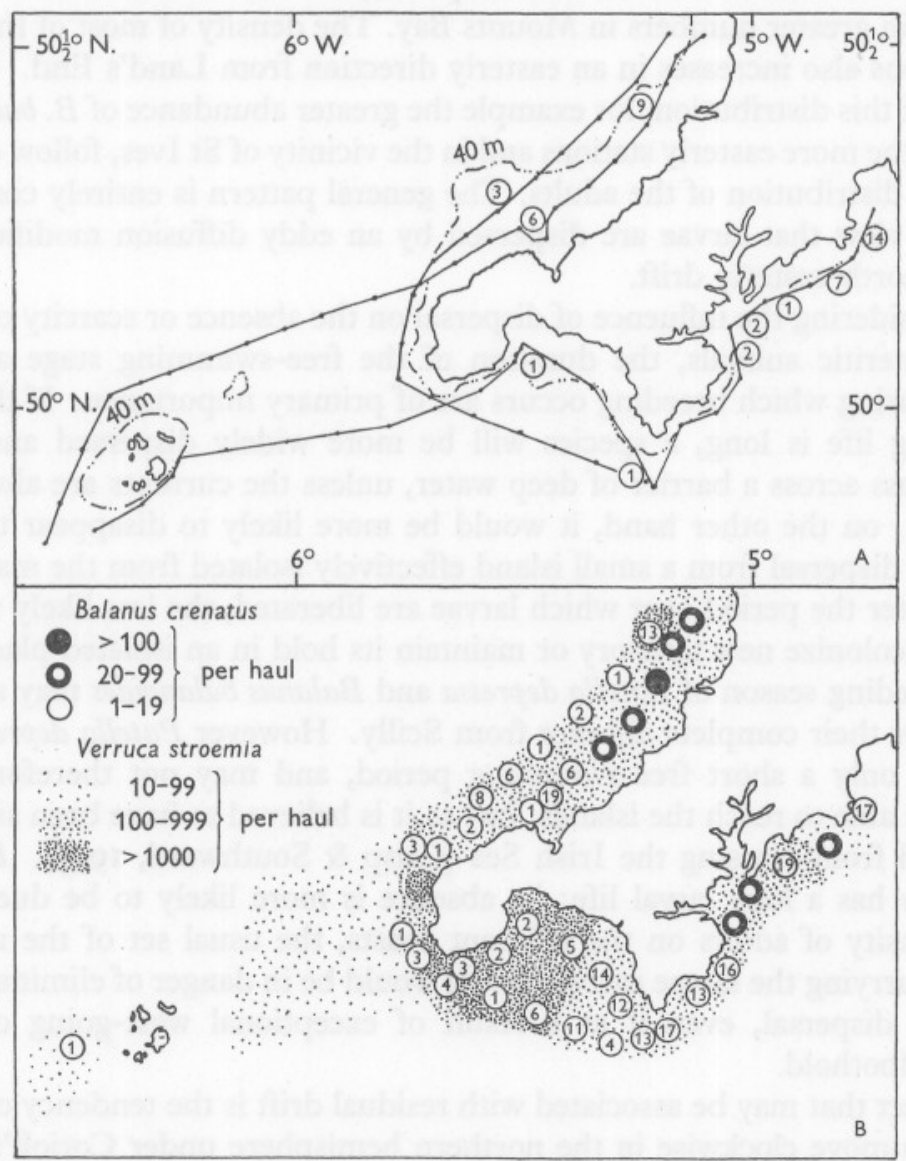

Fig. 7. Distribution of cirripede nauplii off west Cornwall and the Isles of Scilly as shown by samples taken with a standard Hardy plankton indicator, 27-29 March, 1956, towed at approx. $20 \mathrm{~m}$ deep at 8.5 knots. A, numbers of Balanus balanoides per haul of 4 nautical miles; B, numbers of B. crenatus and contours for Verruca stroemia. Positions of hauls, and depth contours are shown on A.

crenatus were very sharp, few larvae being found at distances from the coast exceeding a few miles, even though easterly winds of force 3-6 prevailed during the survey. The western limits of the cirripede larvae coincided with the main boundary between relatively oceanic plankton organisms (Sagitta elegans, Candacia) and neritic forms (Podon, Evadne, Sagitta setosa). The adults 
of both Balanus crenatus and Verruca are found in the infralittoral zone, but the larval distribution indicates that while Verruca may extend some way offshore in this region, Balanus crenatus is almost entirely confined to the coastal belt. The maps show that larval populations of all three species form only a narrow belt at extreme western points, but accumulate over a broader area and in greater numbers in Mounts Bay. The density of most of the larval populations also increases in an easterly direction from Land's End. Certain aspects of this distribution, for example the greater abundance of $B$. balanoides larvae at the more easterly stations and in the vicinity of St Ives, follow directly from the distribution of the adults. The general pattern is entirely consistent with the view that larvae are dispersed by an eddy diffusion modified by a general north-easterly drift.

In considering the influence of dispersal on the absence or scarcity of intertidal or neritic animals, the duration of the free-swimming stage and the period during which breeding occurs are of primary importance. If the freeswimming life is long, a species will be more widely dispersed and more readily pass across a barrier of deep water, unless the currents are always set against it; on the other hand, it would be more likely to disappear through excessive dispersal from a small island effectively isolated from the mainland. The shorter the period over which larvae are liberated, the less likely will the animal recolonize new territory or maintain its hold in an isolated place. The short breeding season of Patella depressa and Balanus balanoides may account in part for their complete absence from Scilly. However Patella depressa has probably only a short free-swimming period, and may not therefore have ever been able to reach the islands, just as it is believed to have been similarly prevented from crossing the Irish Sea (Crisp \& Southward, I953). Balanus balanoides has a long larval life; its absence is more likely to be due to the small density of adults on the adjacent coasts, the usual set of the residual current carrying the larvae eastwards. It would be in danger of elimination by excessive dispersal, even if as a result of exceptional west-going drifts it gained a foothold.

An effect that may be associated with residual drift is the tendency of water masses to move clockwise in the northern hemisphere under Corioli's force. This might result in a greater eastward movement, and better retention of larvae, near the French coast. Southern forms should therefore be carried farther westward on this side of the Channel, though the magnitude of the effect is difficult to determine.

\section{Faunal continuity}

Intertidal forms can spread much more readily along a continuous shoreline than across sea passages (Crisp \& Southward, I953; Southward \& Crisp, 1954b). Hence the continuity of the French coast of the Channel with the Atlantic coasts of France and Spain may allow the survival in the Channel 
of some species which, in isolation, would disappear. The case of Pachygrapsus marmoratus, which was able to establish itself locally only during favourable periods (Prenant, I929), illustrates the importance of continuity. It is possible that species such as Gibbula pennanti and Paracentrotus lividus, which are absent from the English side, can be replenished more easily on the French side by larvae from outside the Channel after periods of unfavourable temperature. Purely infralittoral forms, such as Octopus vulgaris (Rees \& Lumby, I954), may also be influenced strongly by continuity.

\section{Effect of suspended particles in the water}

We have noted briefly that some of the algae may be excluded from the eastern part of the Channel partly by the opacity of the water. To these organisms such a factor may be more important than aspect or dispersal, and needs examining in more detail. The reduced amount of light received in the lower intertidal zone, where the water is silty, is probably most detrimental to the infralittoral and lower midlittoral species. The fucoids can withstand greater exposure to air, and hence can occur at higher levels on the shore, where they remain sufficiently illuminated for photosynthesis (cf. Burrows \& Lodge, I95I). Forms such as Himanthalia and Bifurcaria cannot occur at higher levels out of the water, and will thus be unable to compensate for the reduced illumination of silty water. They will grow best where the water is clear and the tidal range smallest, for under these conditions they can remain permanently immersed with minimum loss of illumination (cf. Fischer-Piette, 1936). Any effects of reduced illumination caused by particulate matter in the eastern basin will be slightly accentuated by differences in the tidal regime. In the western basin low water of spring tides, and high water of neap tides occur at midday, while the opposite is true for the eastern half of the Channel. This difference means that, on average, there is a slightly thicker layer of water over the intertidal zone during daylight hours in the eastern basin in places where the tidal range is identical.

It is interesting to note that the absence or scarcity of Himanthalia and Bifurcaria in the eastern part of the Channel is paralleled in the inner parts of Lyme Bay and the Gulf of St Malo (Fischer-Piette, 1936; Lami, I94I). The shores of these two regions are erodible or scoured, there is more silt in suspension, and the tidal range is greater than farther east (in Dorset, north Cotentin and the Channel Islands) where these algae reappear in some abundance.

\section{Effects of other factors}

Other factors have so far not been adequately demonstrated, and at present there appears no need to invoke them to account for differences in distribution (see p. 158), though their possible existence has been frequently postulated. Smith (1953) has suggested that adsorption of trace constituents on particulate 
matter may contribute to the poverty of the fauna of the eastern part of the Channel and southern North Sea. Because of the limited adsorption capacity of such particles it is difficult to see how this process could continue unless the adsorption was a prelude to destruction or transformation of the substances adsorbed. This is by no means impossible, for particulate matter is the normal site of bacterial action.

\section{CONCLUSIONS AND SUGGESTIONS FOR FURTHER WORK}

It has been shown that the general distribution of many of the organisms investigated may be explained by differences in temperature along the Channel. The existence of critical limits for several species rather than a series of graded boundaries for each species can be accounted for by the modifying effects of additional environmental factors, especially the character of the substratum, the effect of water movement on the dispersal of larvae and the aspect of the shoreline.

It seems unlikely that further faunistic work can establish with certainty our views as to the causes of the distribution. There are too many independent and unmeasurable variables. However, careful and regular observations in certain areas, and further complete surveys from time to time may make it possible to relate the abundance of certain animals to climatic trends, and hence to temperature, or with some other variable.

Further work on the distribution of animals in other habitats would be useful, especially habitats such as sands, muds, crevices, which offer similar conditions and escape certain of the possible modifying influences such as wave-exposure, scour, and aspect. In particular, investigations could well be made of the bottom fauna of representative stations along the length of the Channel. It is clear from the work of Rees (I950) and Rees \& Lumby (I954) that the distribution of Octopus vulgaris, a southern form, shows east-west and north-south trends similar to those of many intertidal organisms. This species, moreover, shows fluctuations in abundance of adults and larvae correlated with fluctuations of sea temperature, especially of the winter months (Rees \& Lumby, 1954).

East-west distribution trends are also found among planktonic animals in the Channel. There is, for example, a sharp boundary in the western basin between relatively oceanic species to the west and neritic species to the east (Russell, 1935). This line, however, lies well to the west of the boundary of the intertidal organisms, with which it appears to have little relation. A somewhat nearer approach to the intertidal boundaries is shown by the line dividing the copepod Centropages typicus in the western basin from the related species C. hamatus which is largely confined to the eastern basin and the Gulf of St Malo (Cushing, 1957). The different distribution of these two species has been attributed by Cushing to differences in water currents and bottom 
deposits in the two basins, factors we have already suggested may be responsible in part for some of the distributions of intertidal organisms. More correlation between temperature and east-west trends may be found with the pilchard, Sardina pilchardus, which is largely confined to the western basin (and Celtic sea) in winter, migration into, and spawning in the eastern basin occurring only during the warmer summer months (see Cushing, 1957).

Only further work on the fluctuations of the boundaries of the planktonic organisms can show whether there is, in fact, any relation between the distributions of these species and of intertidal and bottom-living organisms.

It seems unlikely that experiments on the tolerance of animals to temperature extremes will be immediately relevant to understanding the effect of temperature in distribution. This is more likely to be furthered by studies of the behaviour, nutrition and reproduction of the various animals and plants with special regard to their efficiency and success in natural competition. The latter calls for investigations of suitable animals kept for prolonged periods at a series of temperatures and with various conditions of feeding.

The effects of dispersal on the free-swimming stages is a problem that has been given too little attention in the past and one which offers results equally valuable to the biologist and the hydrographer. Each larva is a clock, set in motion at the moment of liberation from the adult and carried passively from its place of origin by tides and currents. Taken in conjunction with the distribution of adults, quantitative measurements of planktonic larvae can give information on the dynamics of distribution and dispersal of the animals as well as on the direction of local water movements.

During the course of the work we have had the assistance, from time to time, of many friends and colleagues to whom thanks are due: in particular we should like to mention Dr Eve C. Southward, Mr L. W. G. Jones and Mr E. Norris. We are indebted to the Browne Fund of the Royal Society for grants which assisted us in carrying out parts of the field work. Additional financial aid was received by one of us (A.J.S.) from the Department of Scientific and Industrial Research (Senior Research Award), the University of Liverpool and the Marine Biological Association.

\section{SUMMARY}

The English Channel may conveniently be divided into a western basin and an eastern basin separated by a line drawn approximately between the Cherbourg peninsula and the Isle of Wight. In these basins, the environmental factors are very different. Thus the water of the western basin is on average warmer and slightly more saline than that of the eastern basin and its temperature variation is less extreme. The French side of the Channel is warmer than the English coast only in the western basin. The tidal oscillations in the two basins 
are out of phase with each other and the strongest tidal currents occur where the two basins join. The main residual flow is up-Channel with minor coastal eddies.

The shores at the western end of the Channel are generally rocky, they are close to deep water, and so are exposed to frequent heavy swells. The shores of the eastern basin are generally erodible, and accumulations of sand and shingle tend to reduce the force of the waves. The water of the eastern basin generally contains more suspended matter and the shores are usually scoured by sand and shingle.

The distribution of the following animals is given in some detail and compared with earlier records: Anemonia sulcata, Actinia equina, Chthamalus stellatus, Balanus balanoides, B. perforatus, B. crenatus, B. improvisus, Elminius modestus, Verruca stroemia, Hemioniscus balani, Patella vulgata, P. depressa, $P$. aspera, Monodonta lineata, Gibbula umbilicalis, G. pennanti, G. cineraria, Littorina saxatilis, L. littoralis, L. littorea, L. neritoides, Paracentrotus lividus. The distribution of certain other species is also discussed: Balanus balanus, Haliotis tuberculata, Gibbula magus and Calliostoma zizyphinum. The distributions of the following plants are briefly discussed: Laminaria ochroleuca, $L$. digitata, L. hyperborea, L. saccharina, Saccorhiza polysichides, Alaria esculenta, Ascophyllum nodosum, Pelvetia canaliculata, Fucus spiralis, F. vesiculosus, $F$. serratus, Himanthalia elongata and Bifurcaria rotunda.

The main trend in distribution is from east to west. Northern forms are mostly found throughout the Channel though commoner at the eastern end. Many southern forms common in the western basin fail to penetrate the eastern basin, and the fauna at the eastern end of the Channel is therefore impoverished as compared with the richer fauna of the western basin. Certain southern forms are found in the western basin only on the French side of the Channel; others extend farther eastwards on the French side than on the English side.

The trends in distribution are considered to be due to temperature differences. The eastern limits of southern forms are considered to result, not from a lethal effect of a minimum temperature, but from the generally lower efficiency of these animals in comparison with northern forms as the temperature falls. The substratum of most of the eastern basin of the Channel, especially on the English side, is inimical to many rock-living organisms, and it seems probable that this reinforces any adverse effects due to the lowering of average temperature.

The limits of many predominantly southern species occur somewhat abruptly on both north and south coasts of the Channel in the region lying roughly midway between the two basins. This concentration of faunistic limits is believed to be due partly to the changes in the aspect of the coast, which expose it to the north and east winds, and partly to excessive dispersal of larvae by tidal currents which are maximal in these regions. 
The influence of residual drift may be important to the distribution of certain organisms at the extreme west of the Channel, viz. Balanus perforatus, B. balanoides, B. crenatus, Patella depressa, Littorina littorea and Mytilus edulis. Balanus balanoides and Patella depressa are absent from the Isles of Scilly.

The clarity of the water, the tidal range, and the tidal regime (i.e. time of high and low spring tides) appear important to certain algae such as Himanthalia and Bifurcaria. Heavy swell appears essential to Alaria esculenta, and this rather than temperature confines it to the western part of the Channel.

Further work on the behaviour, nutrition and breeding of certain of the animals from rocky shores at a series of temperatures seems desirable, together with a study of distributions of animals from other habitats. The mechanism of dispersal and the distribution of larvae of shore animals also deserve more attention.

\section{REFERENCES}

AIr Ministry, 1936. Averages of Temperature for the British Isles for Periods Ending 1935. London: H.M.S.O.

Andrewartha, H. G. \& Birch, L. C., 1954. The Distribution and Abundance of Animals. Chicago: University Press.

APELlÖF, A., 1912. Invertebrate bottom fauna of the Norwegian Sea and the north Atlantic. In Murray, J. \& HJort, J., The Depths of the Ocean, pp. 457-560. London: Macmillan.

BARNES, H., I956. Balanus balanoides L. in the Firth of Clyde: the development and annual variation of the larval population and the causative factors. F. Anim. Ecol., Vol. 25, pp. 72-84.

BASsINDALE, R., 1936. The developmental stages of three English barnacles, Balanus balanoides (Linn.), Chthamalus stellatus (Poli) and Verruca stroemia (O. F. Müller). Proc. zool. Soc. Lond., 1936, pp. 57-74.

- 194I. The invertebrate fauna of the southern shores of the Bristol Channel and Severn estuary. Proc. Bristol Nat. Soc., Ser. 4, Vol. 9, pp. I43-20I.

Bigelow, H. B. \& Edmonson, W. T., 1947. Wind Waves at Sea, Breakers and Surf. Washington: U.S. Navy Department, Hydrographic Office.

Bishop, M. W. H. \& CrisP, D. J., 1957. The Australasian barnacle, Elminius modestus, in France. Nature, Lond., Vol. I79, pp. 482-3.

- 1958. The distribution of Elminius modestus in France. (In the Press.)

BowDEN, K. F., 1956. The flow of water through the Straits of Dover related to wind and differences in sea level. Phil. Trans. A, Vol. 248, pp. 5I7-5I.

BurRows, E. M. \& LODGE, S. M., I95I. Autecology and the species problem in Fucus. 7. mar. biol. Ass. U.K., Vol. 30, pp. 161-76.

Børgesen, F. \& Jónsson, H., I908. The distribution of the marine algae of the Arctic Sea, and of the northernmost part of the Atlantic. Botany of the Faeröes, Pt. 3, Appendix, 28 pp.

CARRUTHERS, J. N., I930. Further investigations upon the water movements in the English Channel. Drift-bottle experiments in the summers of 1927, 1928 and 1929, with critical notes. F. mar. biol. Ass. U.K., Vol. 17, pp. 24I-75.

- I935. The flow of water through the Straits of Dover as gauged by continuous current meter observations at the Varne lightvessel ( $50^{\circ} 56^{\prime} \mathrm{N}$., $\mathrm{I}^{\circ} \mathrm{I} 7^{\prime} \mathrm{E}$.). Pt. II. Second report on results obtained. Fish. Invest., Lond., Ser. 2, Vol. 14, No. 4. 
CARRUthers, J. N., LAwFord, A. L. \& Veley, V. F. C., I950. Studies of water movements at various light vessels in 1938, 1939 and 1940. I. At the 'Varne' lightship and her successors. Ann. biol., Copenhague, T. 6, pp. II5-2I.

Carruthers, J. N., Lawford, A. L., Veley, V. F. C. \& Gruning, J. F., I95I. Studies of water movements and winds at various lightvessels. II. At the Seven Stones light vessel near the Scilly Isles. F. mar. biol. Ass. U.K., Vol. 29, pp. 587-608.

CLARK, J., I906. Marine Zoology. In The Victoria History of the County of Cornwall, pp. II3-59. London.

Colman, J., I933. The nature of the intertidal zonation of plants and animals. F. mar. biol. Ass. U.K., Vol. 18, pp. 435-76.

Cooper, L. H. N., 1958. Sea temperatures in Plymouth Sound. F. mar. biol. Ass. U.K., Vol. 37, pp. I-3.

CRISP, D. J., 1950. Breeding and distribution of Chthamalus stellatus. Nature, Lond., Vol. 166, p. 3Ir.

- 1956. The intertidal zoology of Rockall. In FISHER, J., Rockall. London: Bles. 1958. The spread of Elminius modestus in north-west Europe. F. mar. biol. Ass. U.K., Vol. 37 (in the Press.)

Crisp, D. J. \& ChIPperfield, P. N. J., I948. Occurrence of Elminius modestus (Darwin) in British waters. Nature, Lond., Vol. I6I, p. 64.

CRISP, D. J. \& KNIGHT-Jones, E. W., 1955. Discontinuities in the distribution of shore animals in North Wales. Rep. Bardsey Observatory, Year 1954, pp. 29-34.

Crisp, D. J. \& MOlesworth, A. N. H., I95I. Habitat of Balanus amphitrite var. denticulata in Britain. Nature, Lond., Vol. 167, p. 489.

CRISP, D. J. \& SOUTHWARD, A. J., I953. Isolation of intertidal animals by sea barriers. Nature, Lond., Vol. 172, p. 208.

Crofts, D. R., 1929. Haliotis. Mem. Lpool mar. biol. Com., No. 29, 174 pp.

Cushing, D. H., 1957. The number of Pilchards in the Channel. Fish. Invest., Lond., ser. 2, Vol. 2I, No. 5, 27 pp.

Darwin, C., 1854. A Monograph on the Sub-Class Cirripedia: Balanidae, Verrucidae, etc. London: Ray Soc.

- 1872. The Origin of Species by Means of Natural Selection, 6th ed., ch. 3 . London: John Murray.

Dizerbo, A. H., I947. La répartition et la zône de végétation dans le massif armoricaine d'Alaria esculenta (L.) Grev. Bull. Soc. sci. Bretagne, T. 22, pp. I13-I7.

DoDD, J. M., 1957. Artificial fertilisation, larval development and metamorphosis in Patella vulgata L. and Patella caerulea L. Pubbl. Staz. zool. Napoli, Vol. 29, pp. $172-86$.

Evans, R. G., 1953. Studies on the biology of British limpets-the genus Patella on the south coast of England. Proc. zool. Soc., Lond., Vol. 132, pp. 357-76.

FIsCHER, E., I928. Sur la distribution géographique de quelques organismes de rocher le long des côtes de la Manche. Trav. Lab. Mus. Hist. nat. St-Servan, T. 2, pp. I-I6.

Fischer-PIETTE, E., I932. Répartition des principales espèces fixées sur les rochers battus des côtes et des îles de la Manche, de Lannion à Fécamp. Ann. Inst. océanogr. Monaco, T. 12, pp. 107-213.

- 1935. Systematique et biogéographie. Les Patelles d'Europe et d'Afrique du Nord. F. Conchyliol., T. 79, pp. 5-66.

1936. Études sur la biogéographie intercotidale des deux rives de la Manche. f. Linn. Soc. (Zool.), Vol. 40, pp. 181-272.

- 1955. Répartition, le long des côtes septentrionales de l'Espagne, des principales espèces peuplant les rochers intercotidaux. Ann. Inst. océanogr. Monaco, T. 3I, pp. 37-124. 
Fischer-Piette, E. \& Prenant, M., 1956. Distribution des cirripèdes intercotidaux d'Espagne septentrionale. Bull. Cent. Rech. sci. Biarritz, T. I, pp. 7-19.

Forbes, E. \& Hanley, S., I853. A History of British Mollusca. Vols. 2 \& 3. London: Van Voorst.

GaIllard, J. M., I954. Revision des espèces des côtes de France du genre Gibbula Risso (Mollusque Prosobranche). Bull. Mus. Hist. nat., Paris, T. 26, pp. 238-43.

Hamel, G., 1931-39. Phéophycées de France. Paris.

HARTOG, C. DEN, I956. Speculations on the immigration of the barnacle Elminius modestus in France. Beaufortia, Vol. 5, p. I4I.

HaRvey, H. W., I930. Hydrography of the mouth of the English Channel I925-I928. 7. mar. biol. Ass. U.K., Vol. I6, pp. 791-820.

HaWkshaw, C., I878. On the action of limpets in sucking pits in and eroding the surface of chalk at Dover. F. Linn. Soc. (Zool.), Vol. I4, pp. 406-I I.

KaLle, K., 1937. Nährstoff-Untersuchungen als Hydrographisches Hilfsmittel zur Unterscheidung von Wasserkörpern. Ann. Hydrogr. Berl., Jahrg. 65, pp. I-I8.

KoEHLER, R., I884. Recherches sur la faune marine des îles Anglo-Normandes. Bull. Soc. Sci. Nancy, r884, pp. 5I-99.

LAMI, R., I94I. Notules d'algologie marine (suite). III. Sur l'écologie de Bifurcaria tuberculata dans la région malouine. Bull. Lab. marit. Dinard, F. 23, pp. 24-29.

- I943. Notules d'algologie marine (suite). IX. Sur l'écologie et la répartition dans la Manche de Laminaria ochroleuca De La Pylaie. Bull. Lab. marit. Dinard, F. 25 , pp. $75-90$.

- 1954. Une station normande de Laminaria ochroleuca de la Pylaie. Trav. algol., N.S., T. I, pp. 44-45.

Lebour, M. V., I937. The eggs and larvae of the British prosobranchs with special reference to those living in the plankton. F. mar. biol. Ass. U.K., Vol. 22, pp. $105-66$.

Lillyy, S. J., Sloane, J. F., Bassindale, R., Ebling, F. J. \& Kitching, J. A., I953. The ecology of Lough Ine rapids with special reference to water currents. IV. The sedentary fauna of sub-littoral boulders. F. Anim. Ecol., Vol. 22, pp. 87-I22.

Lumby, J. R., I935. Salinity and temperature of the English Channel. Atlas of charts. Fish. Invest., Lond., Ser. 2, Vol. 14, No. 3.

LYSAGHT, A. M., 194I. The biology and trematode parasites of the gastropod Littorina neritoides (L.) on the Plymouth Breakwater. F. mar. biol. Ass. U.K., Vol. 25, pp. $4 \mathrm{I}-67$.

Maghraby, A. M. el \& Perkins, E. J., 1956. Additions to the marine fauna of Whitstable. Ann. Mag. nat. Hist., Ser. 12, Vol. 9, pp. 48I-96.

Mansell-Pleydell, J. C., I898. The Mollusca of Dorsetshire. Dorchester: Dorset County Chronicle.

Marine Biological Association, 1957. Plymouth Marine Fauna, 3rd ed. Plymouth.

Martonne, E. DE, 1935. Traité de Géographie Physique. Paris.

Moore, H. B., 1935. The biology of Balanus balanoides. IV. Relation to environmental factors. F. mar. biol. Ass. U.K., Vol. 20, pp. 273-307.

Moore, H. B. \& Kitching, J. A., I939. The biology of Chthamalus stellatus (Poli). f. mar. biol. Ass. U.K., Vol. 23, pp. 52 I-4I.

MORTENSEN, T., 1927. Handbook of the Echinoderms of the British Isles. Oxford University Press.

Nobre, A., 1932. Moluscos Marinhos de Portugal. Universidade do Pôrto, Instituto de Zoologia.

NorRIS, E. \& CRISP, D. J., I953. The distribution and planktonic stages of the cirripede Balanus perforatus Brugière. Proc. zool. Soc., Lond., Vol. 123, pp. 393409. 
Office Nationale MÉtÉorologiQue, 1940. Étude climatologique de la Bretagne. Paris.

— 1942 a. Étude climatologique de la Normandie. Paris. I942 b. Étude climatologique de la région Flandre-Artois-Picardie. Paris.

OrToN, J. H., I920. Sea temperature, breeding and distribution in marine animals. f. mar. biol. Ass. U.K., Vol. I2, pp. 339-66.

Orton, J. H., Southward, A. J. \& DodD, J. M., 1956. Studies on the biology of limpets. II. The breeding of Patella vulgata L. in Britain. F. mar. biol. Ass. U.K., Vol. 35, pp. 149-76.

PARKe, M., I948. Laminaria ochroleuca de la Pylaie growing on the coast of Britain. Nature, Lond., Vol. 162, p. 295.

Perez, C., I923. Sur la spécificité du parasitisme des Hemioniscus. Bull. Soc. zool. Fr., T. 48, pp. 375-6.

PILSBRY, H. A., I9I6. The sessile barnacles (Cirripedia) contained in the collections of the U.S. National Museum. Bull. U.S. nat. Mus., Vol. 93, 366 pp.

Prenant, M., I929. Sur l'extension actuelle de Pachygrapsus marmoratus (Fabr.). Bull. Lab. marit. Dinard, F. 4, pp. 3-4.

ReEs, W. J., 1950. The distribution of Octopus vulgaris Lamarck in British waters. F. mar. biol. Ass. U.K., Vol. 29, pp. 36I-78.

ReEs, W. J. \& Lumby, J. R., 1954. The abundance of Octopus in the English Channel. F. mar. biol. Ass. U.K., Vol. 33, pp. 515-36.

RUNNSTRÖM, S., 1929. Weitere Studien über Temperaturanpassung der Fortpflanzung und Entwicklung mariner Tiere. Bergens Mus. Aarb., 1929, No. 10, 46 pp.

RusSELL, F. S., I935. On the value of certain plankton animals as indicators of water movements in the English Channel and North Sea. F. mar. biol. Ass. U.K., Vol. 20, 309-32.

- 1953. The English Channel. Rep. Trans. Dev. Ass. Adv. Sci., Vol. 85, pp. I-I7.

Sars, G. O., 1878. Bidrag til Kundskaben on Norges Arktiske Fauna. I. Mollusca. Christiana.

SineL, J., 1906. An Outline of the Natural History of our Shores. London: Swan Sonnenschein and Co.

Smith, J. E., 1953. Maintenance and spread of sea shore faunas. Advanc. Sci., Lond., Ser. I0, No. 38 , pp. $145-56$.

Southward, A. J., I950. Occurrence of Chthamalus stellatus in the Isle of Man. Nature, Lond., Vol. 165, p. 408.

- 1951. The distribution of Chthamalus stellatus in the Irish Sea. Nature, Lond., Vol. 167, p. 410.

- 1953. The ecology of some rocky shores in the south of the Isle of Man. Proc. Lpool biol. Soc., Vol. 59, pp. I-50.

— 1955a. Feeding of barnacles. Nature, Lond., Vol. 175, p. II24.

- $1955 b$. On the behaviour of barnacles. I. The relation of cirral and other activities to temperature. F. mar. biol. Ass. U.K., Vol. 34, pp. 403-22.

- I955c. On the behaviour of barnacles. II. The influence of habitat and tidelevel on cirral activity. F. mar. biol. Ass. U.K., Vol. 34, pp. 423-33.

- 1957. On the behaviour of barnacles. III. Further observations on the influence of temperature and age on cirral activity. F. mar. biol. Ass. U.K., Vol. 36, pp. $323-34$.

- 1958. Notes on the temperature tolerances of some intertidal animals in relation to environmental temperatures and geographical distribution. f. mar. biol. Ass. U.K., Vol. 37, pp. 49-66.

SouthWARD, A. J. \& CRISP, D. J., I952. Changes in the distribution of the intertidal barnacles in relation to the environment. Nature, Lond., Vol. 170, pp. 416-17. 
Southward, A. J. \& CRISP, D. J., I954a. Changes in the distribution of the intertidal barnacles Chthamalus stellatus Poli and Balanus balanoides L. in the British Isles. F. Anim. Ecol., Vol. 23, pp. 163-77.

- 1954b. The distribution of certain intertidal animals around the Irish coast. Proc. R. Irish Acad., Vol. 57 (B), No. I, 29 pp.

1956. Fluctuations in the distribution and abundance of intertidal barnacles. F. mar. biol. Ass. U.K., Vol. 35, pp. 2 II-29.

SOUTHWARD, A. J. \& ORTON, J. H., 1954. The effects of wave-action on the distribution and numbers of the commoner plants and animals living on the Plymouth breakwater. F. mar. biol. Ass. U.K., Vol. 33, pp. I-I9.

SPOONER, G. M., 1950. Additional records of Laminaria ochroleuca de la Pylaie. F. mar. biol. Ass. U.K., Vol. 29, pp. 26I-2.

StATION BIOLOGIQUE DE ROSCOFF, I95I $a$. Inventaire de la faune marine de Roscoff. Bryozoaires-Echinodermes. Trav. Sta. biol. Roscoff, Suppl. 4, 53 pp.

— I $95 \mathrm{I} b$. Inventaire de la faune marine de Roscoff. Mollusques. Trav. Sta. biol. Roscoff, Suppl. 5, pp. I-80.

- 1954. Inventaire de la flore marine de Roscoff. Algues, Champignons, Lichens et Spermatophytes. Trav. Sta. biol. Roscoff, Suppl. 6, I52 pp.

Stephensen, K., I938. Cirripedia (incl. Rhizocephala). Zool. Iceland, Vol. 3, Pt. 303I, II pp.

Stephenson, T. A., 1924. Notes on Haliotis tuberculata. F. mar. biol. Ass. U.K., Vol. 13, pp. 480-95.

- 1935. The British Sea Anemones, Vol. 2. London: Ray Soc.

Thorson, G., I94I. Marine Gastropoda Prosobranchiata. Zool. Iceland, Vol. 4, Pt. $60,150 \mathrm{pp}$.

- 1946. Reproduction and larval development of Danish marine bottom invertebrates. Medd. Komm. Havundersøg., Kbh., Ser. Plankton, Vol. 4, 423 pp.

TomLIN, J. R. LE B., 1937. Report of the conchological section, 1936. Rep. Soc. guérnesiaise, Vol. I2, pp. 454-5.

VAN Veen, J., 1936. Onderzoekingen in de Hoofden in verband met de gestelheid der Nederlandsche Kust. S'Gravenhage.

Wegmann, H., I884. Contributions à l'histoire naturelle des Haliotides. Arch. Zool. exp. gén., T. 2, pp. 289-378.

Woodward, S. P., 1880. A Manual of the Mollusca, 4th ed. London: Crosby Lockwood and Co. 


\section{APPENDIX}

TABLE 7. THE DETAILED DISTRIBUTION OF THE COMMONER INTERTIDAL ANIMALS IN THE CHANNEL

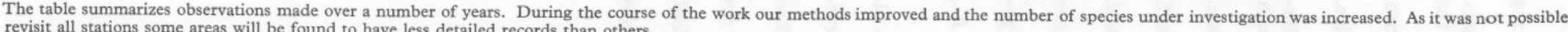
to revisit all stations some areas will be found to have

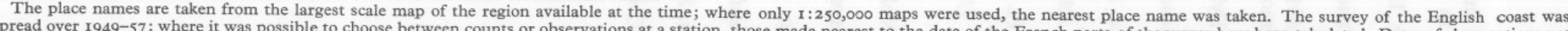

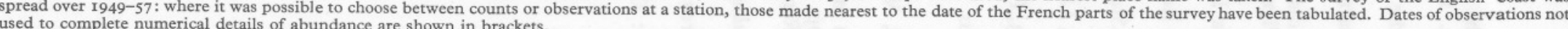

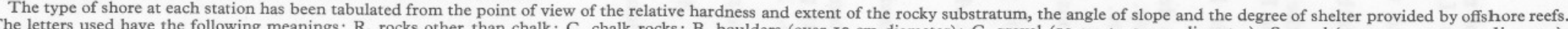

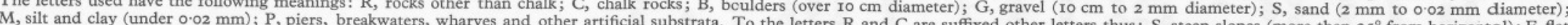

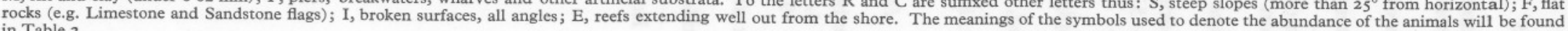
in Table 2.

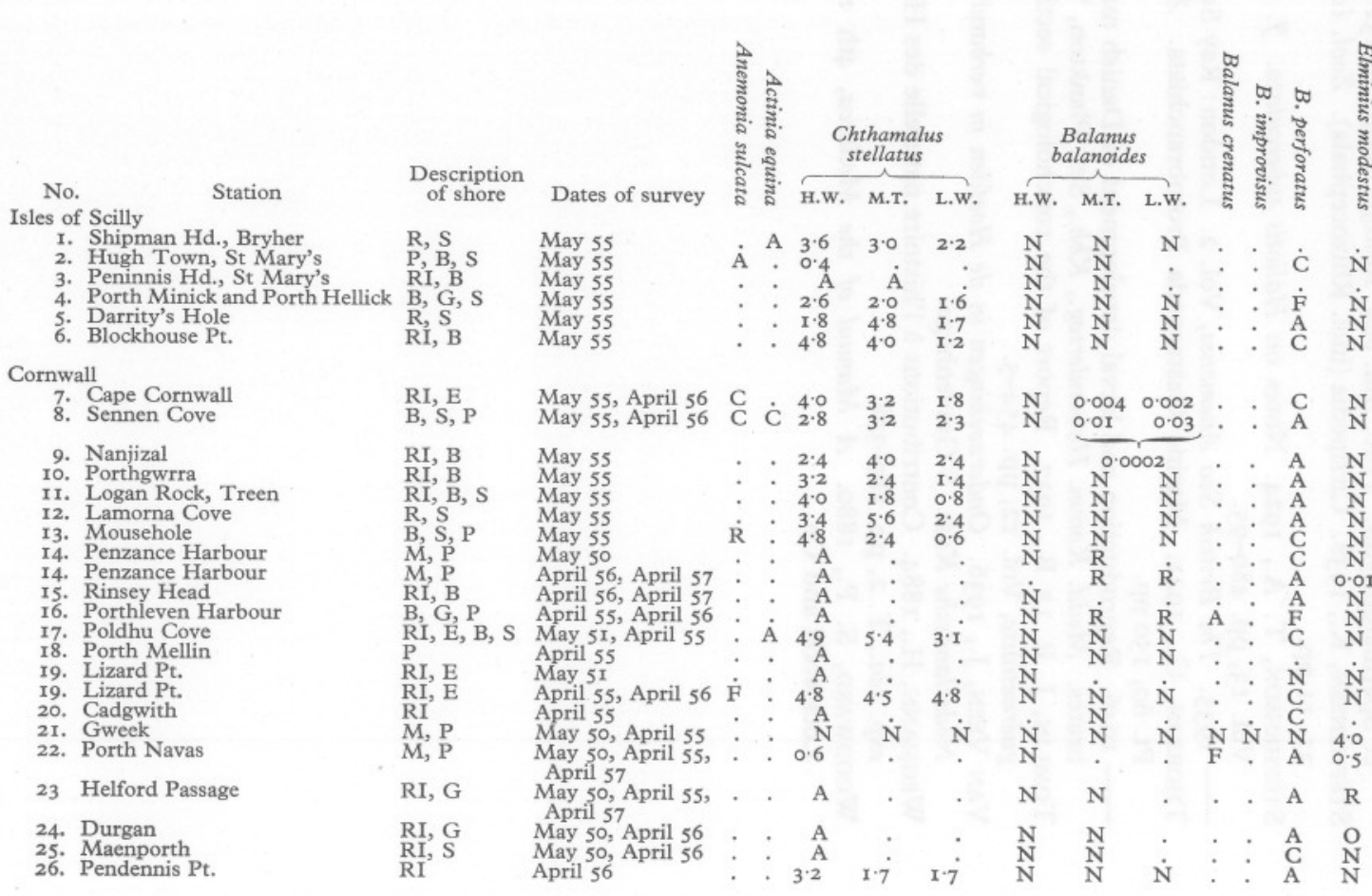




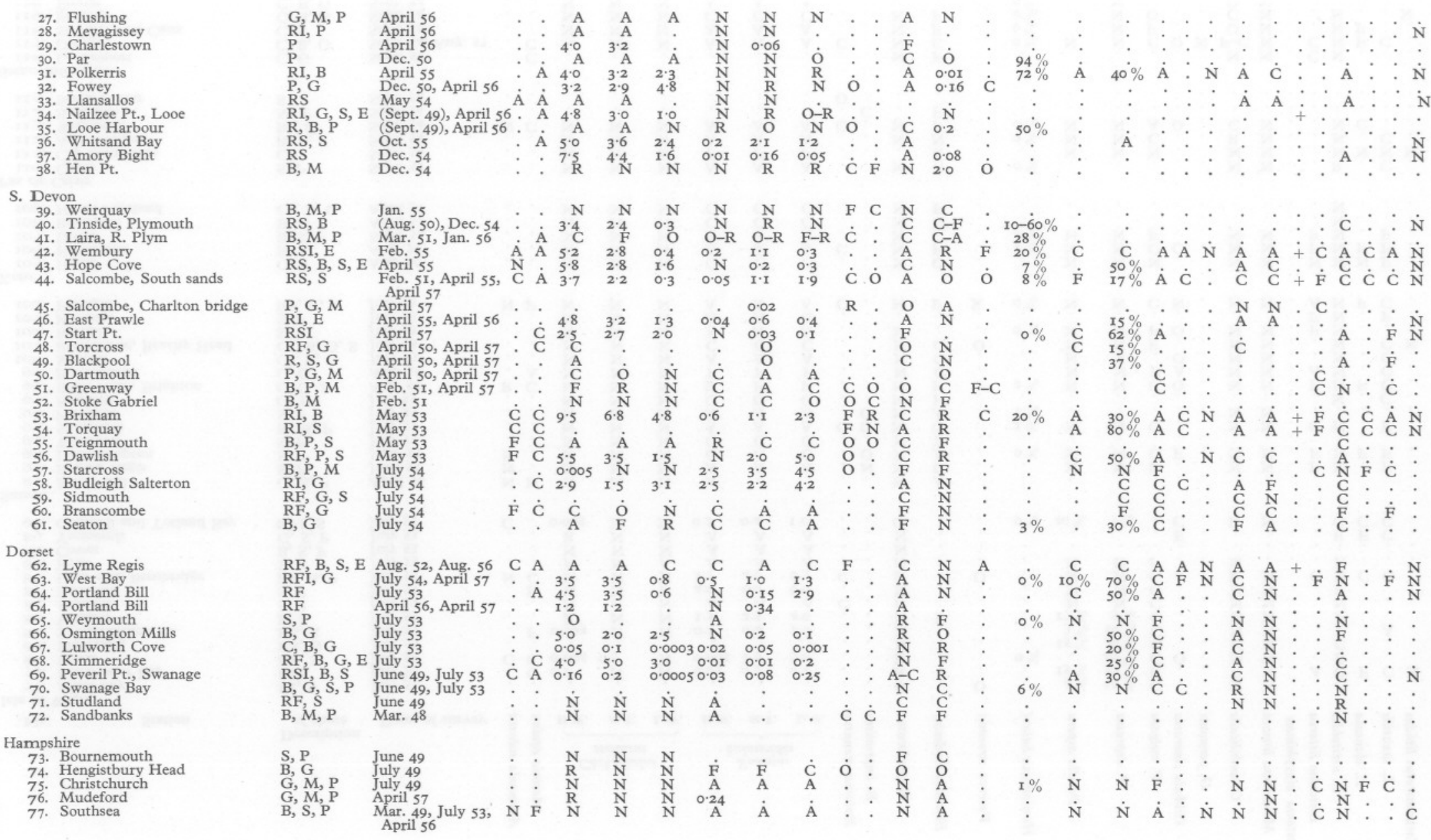


TABLE 7 (continued)

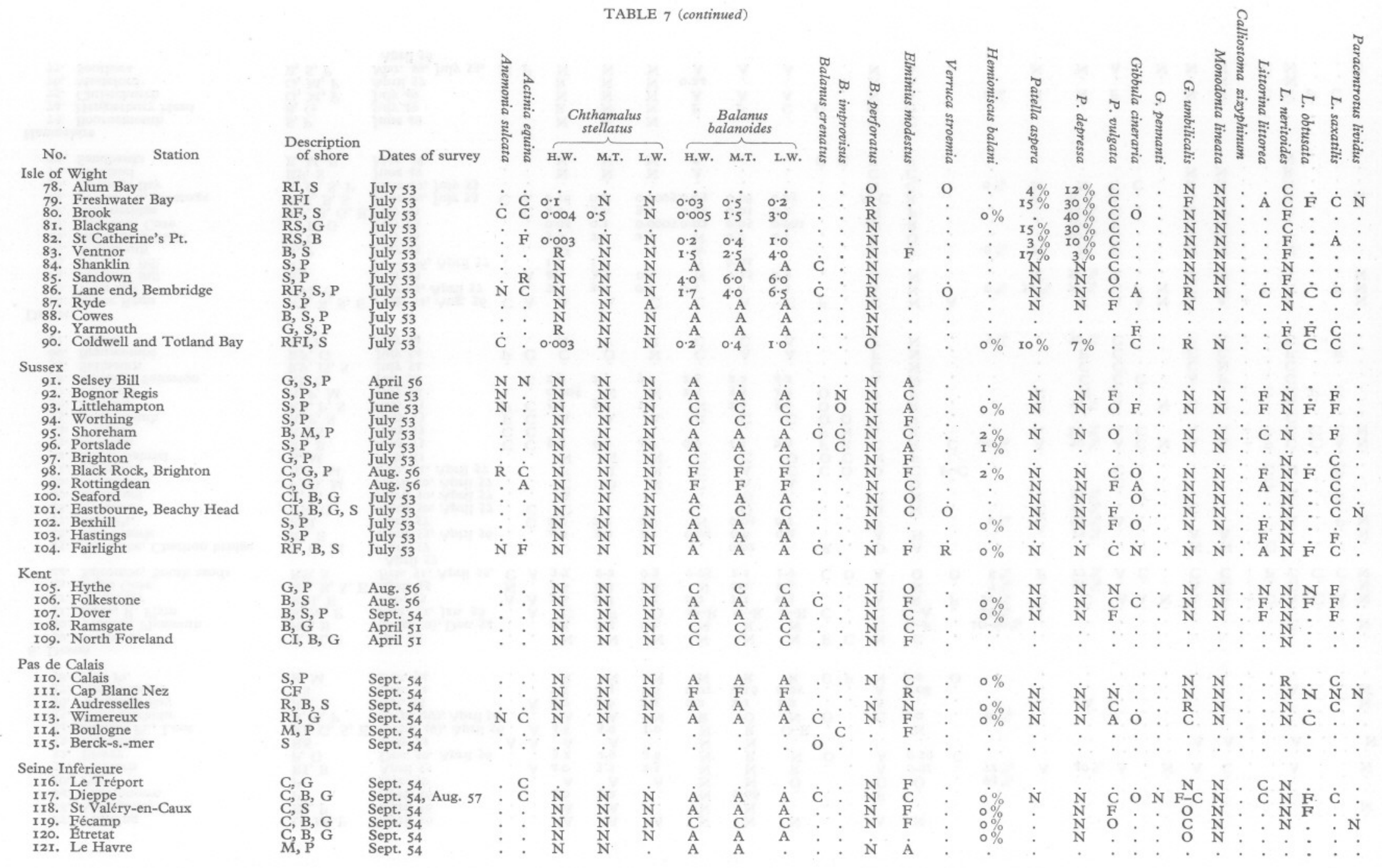




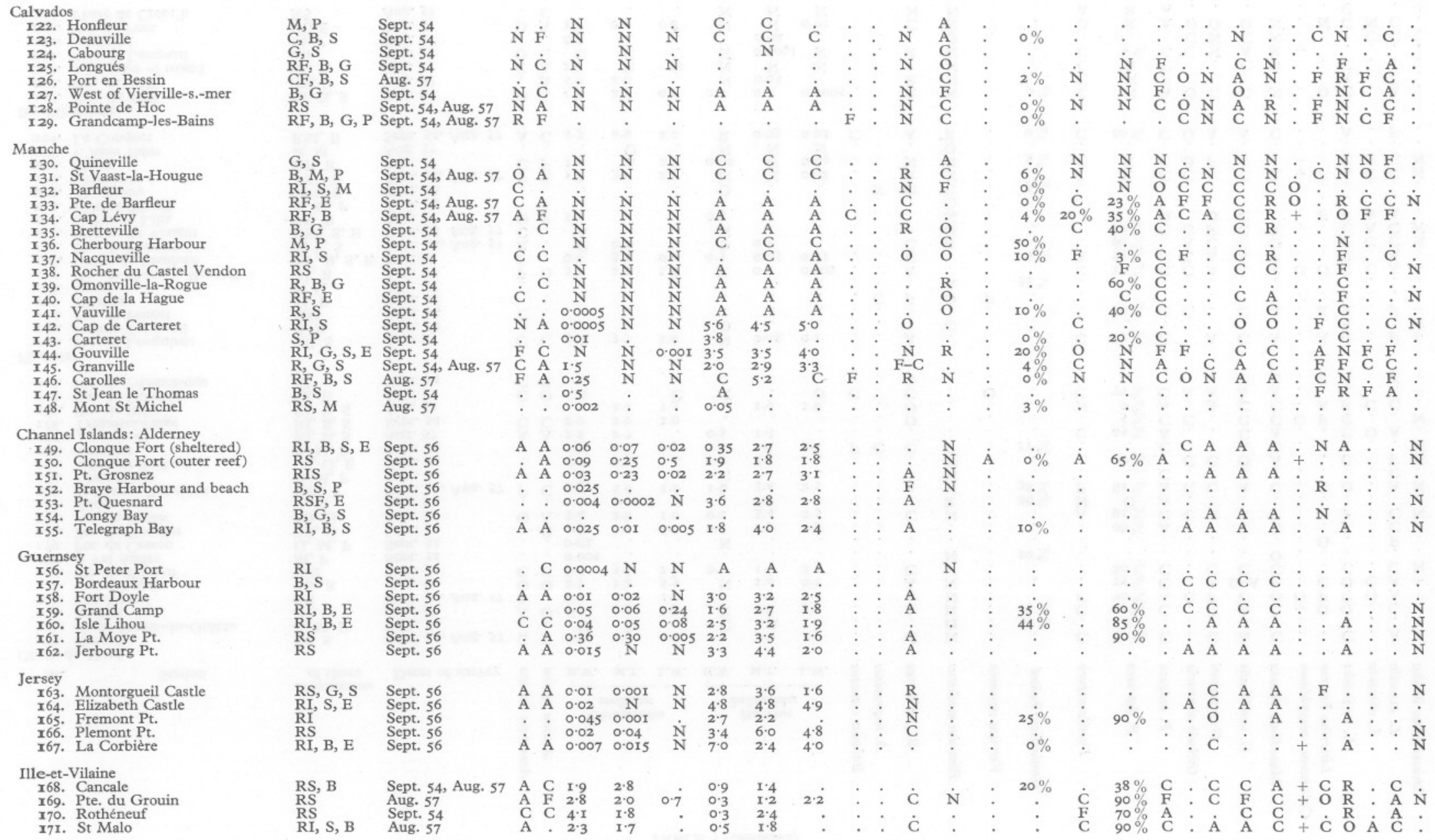


TABLE 7 (continued)

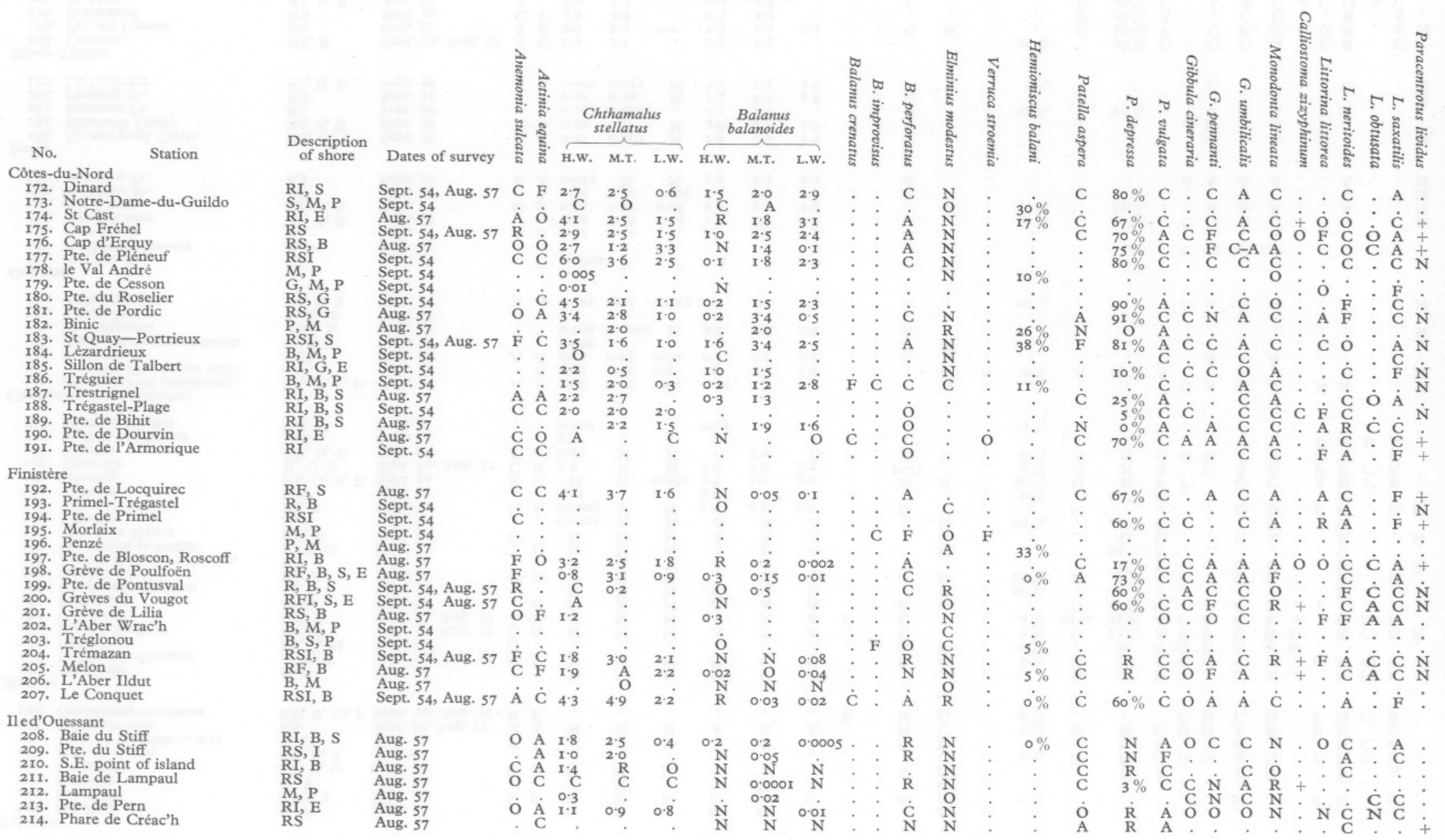

